Dept. of Meat Hygiene,

Fac. Vet. Med., Alex. Unv.

\title{
MICROBIAL ASPECTS OF LAMB MEAT TREATED WITH LACTIC AND ACETIC ACIDS
}

\author{
(With 8 Tables)
}

By

M.M. EBRAHEAM MOUSA and A.A. BKHEET*

*Animal Health Res. Inst. Damanhour Bransh

(Received at 20/4/2009)

الوجهة الميكروبية للحوم الضأن المعاملة بحمضى اللاكتيك والخليك

$$
\text { محد محمد إبراهيم موسسى ، احمد أبو المجل بخيث }
$$

أجريت هذه الدر اسة لتقييم قدرة الأحماض العضوية على تحسين جودة لحوم الضان الطازجة

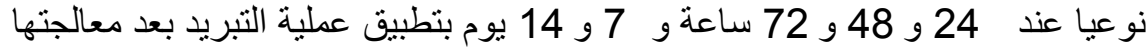

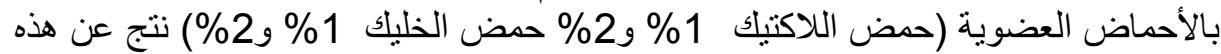

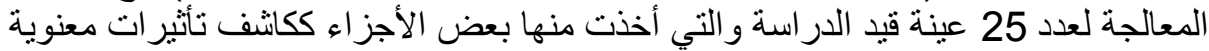

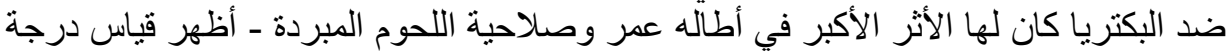

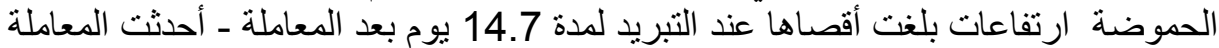

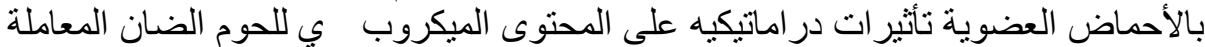

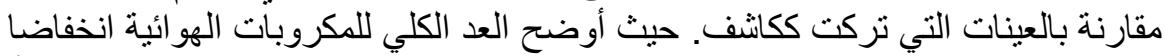

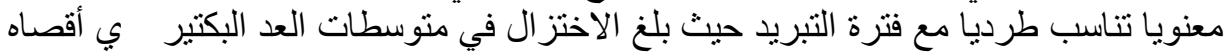

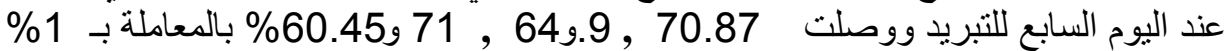

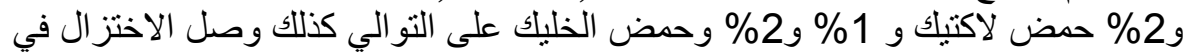

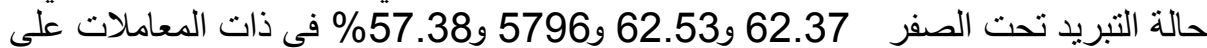

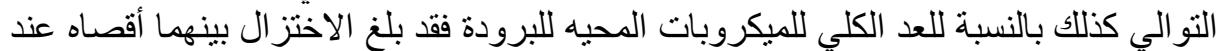

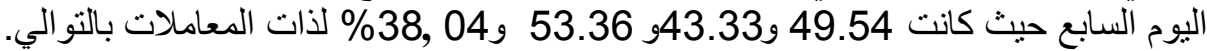

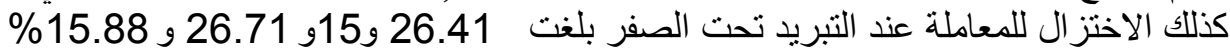

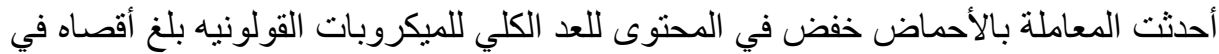

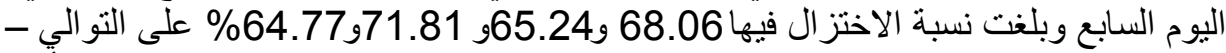

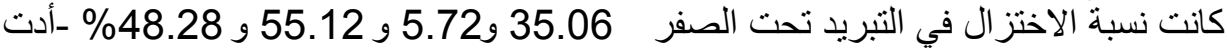

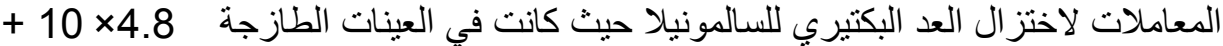

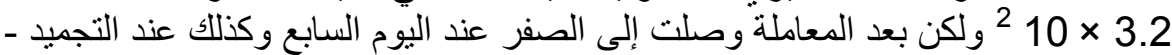

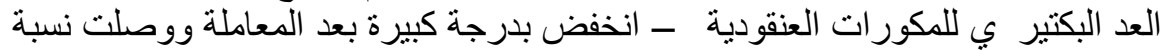

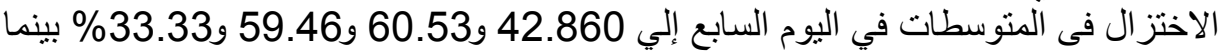
عند التجميد وصل الاختز ال إلي

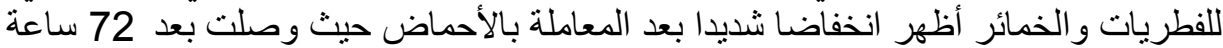
إلي حدود دنيا وبلغ عندها نسبة الاختزال 56.74 و52.07 و52.94 و39.02\% بينما في 


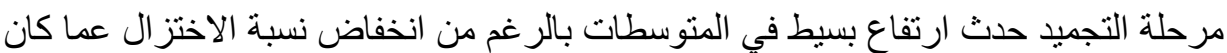

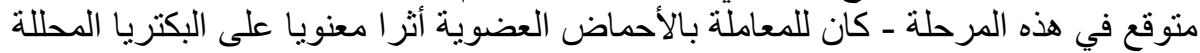
للبروتين حيث وصلت نسبة الاختزال في العد البكتريا لها

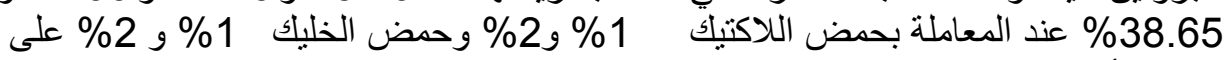

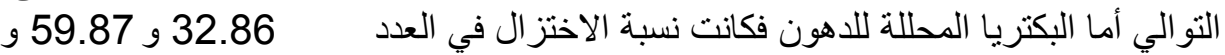

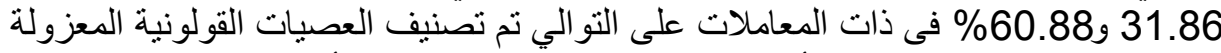

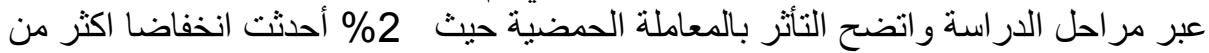

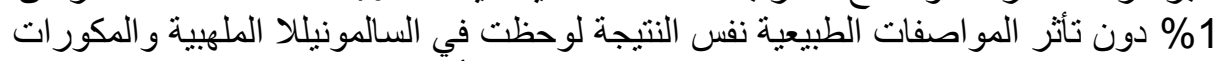

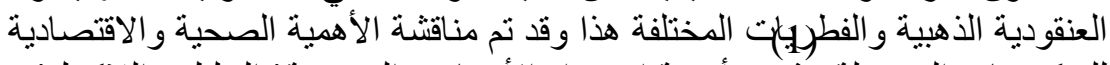

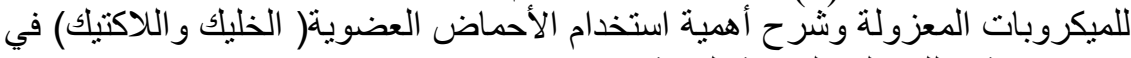

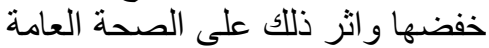

\section{SUMMARY}

The present study was carried out to assess the ability of organic acids to improve the quality of fresh lamb meat chilled at $7 . \mathrm{C}$ for $24,48,72$ hours, $7 \& 14$ day and freezed at $-18 \stackrel{\mathrm{C}}{\mathrm{C}}$ after treatment with organic acids (lactic and acetic 1\&2\%) which resulted in significant improvement of nearly all parameters over the control of 25 samples from different lamb carcasses. Such treatments exerted a significant antibacterial effect which is of public heath importance and prolong the shelf life of carcasses on trial. The $\mathrm{pH}$ value revealed highest record at 14 day chilling. The organic acids revealed dramatic effects as antimicrobial agent. The total aerobic bacterial count revealed reciprocal reduction percent $70.87,64.09,71.07$ and $60.54 \%$ in chilling for 7 day after treatment with $1 \& 2 \%$ lactic and acetic acid respectively. The reciprocal reduction percents were 62.37 to $62 . \mathrm{S} 3 \%$ and 57.96 and $57.38 \%$ in $1 \& 2 \%$ lactic and acetic acids. On applying the psychrophilic bacteria the reciprocal reduction percent means at the $7^{\text {th }}$ day of chilling were $49.54,73.33,53.36$ and $38.04 \%$ respectively with same acids treatments .On apply freezing for one month the reduction values reciprocal to the means were $29.41,15.00,26.71$ and $15.88 \%$ respectively. The lowest records of total coliform counts were shown on the $7^{\text {th }}$ day chilling. The reciprocal reduction percent of means were $73.65,65.04,77.84$ and 68.59. After month of freezing the corresponding reductions were 53.51, 45.51. 63.72 and $45 \%$ with acid treatments respectively. The reduction percent of total Enterobacteriaceae counts of the means were 68.06, 62.24, 71.81and $64.77 \%$ after 7 days of chilling lamb meat post acid treatment. Salmonella count revealed means zero after 7, 14 day of chilling lamb 
meat; also, means were zero after freezing for month post acids treatments. Staphylococcus aureus count: revealed highest reduction at the $7^{\text {th }}$ day post chilling and the reciprocal reductions were $42.86,60.53$, 59.46 and $33.33 \%$ respectively. Total mould and yeast count showed reduction percents of 56.74, 52.07, 52.94 and $39.02 \%$ after 72 hour of treated chilled lamb meat. After freezing, reduction percents were 26.97, $29.75,16.99 \%$ in lactic acid $1,2 \%$ and acetic acid $1 \%$ where count increased in acetic acid $2 \%$. The means of Proteolytic bacterial count reduced to $13.49,42.26,22.99$ and $38.65 \%$ in $1,2 \%$ lactic acid and $1 \&$ $2 \%$ acetic acid treated lamb carcasses. The lipolytic bacterial count reductions were $32.86,59.37,31.86$ and $60.88 \%$ respectively. Coliforms were detected in lower incidence in the treated sample including E.coli, Enterobacter spp, Khlebsiella spp., Edwardesiella tarda and Serratea rubidea. The acid treatment lower the occurrence of coliform where $2 \%$ concentration was more efficient than $1 \%$ The same results were detected in identified Staphylococcus aureus and Salmonella enteritidis in addition to the identified moulds

Key words:

\section{INTRODUCTION}

Meat is an important vehicle for food borne diseases such as salmonellosis and campylo bacteriosis. Many other organisms act as toxin producers and spoilage formers. Organic acids including acetic, fumaric, propionic, and lactic acids are added to foods to prevent or delay the growth of pathogenic or spoilage bacteria. The inhibitory effects of acids on microbial growth has long been used to preserve foods from spoilage (Podolak, et al., 1996).

The external contamination of meat constitute a constant problem in meat developing countries where the abattoirs itself have a large numbers of potential sources of contamination (Davis et al., 2000). Organic acids as antimicrobial agents for surface treatment of fresh meat have been used to prevent the growth bacteria during chill storage (ICMSF, 1982). Similarly in Europe it is considered a harmless constituent (leuck, 1980). This widely knowledge about absence of acute and chronic toxicity has led to the choice of lactic acid as decontaminating agent in food industry. Data are available on the potency of lactic acid spray as carcass decontaminant for lamb and beef (Fatema-Ali, 2001) Lactic and acetic acids are generally recognized as safe food additives. Both acids are based as apart of meat 
decontamination procedures, where they are more effective than many other technique and components (Gorman, et al., 1997). Numerous studies have reported on the effects of organic acids on bacterial populations as well as some pathogenic organisms (Dickson and Anderson, 1991, Hardin, et al., 1995 and Castillo, et al., 2001).

The object of the current research was to evaluate the effectiveness of acetic and lactic acids on microbial loads and characteristics of treated lamb carcasses across the chilling and freezing time.

\section{MATERIALS and METHODS}

- Collection of samples: From a total of 25 fresh representative lamb carcasses, randomly collected from different butchers shops at Behaira province, right fore limb and left hind limb were taken and packed in insulating containers and transferred as soon as possible to the laboratory for microbiological examination

- Treatment of samples: The fresh samples without treatment were taken as control. Samples were sprayed with aqueous solutions of lactic acid 1 and $2 \%$, others were sprayed with acetic acid 1 and $2 \%$ and all samples were hanged for ten minutes to dry. Samples were put in chilling at $7 \circ \mathrm{C}$ for $24,48,72$ hours, 7 and 14 days and frozen at $-18 . \mathrm{C}$ for one month.

- Preparation of samples were done according to ICMSF (1982)

- Measurement of PH was determined by using Digital pH. Meter

- Microbial Examination

- Determination of Total aerobic bacterial count according to ICMSF (1982)

- Determination of Psychrophilic bacterial count according to ICMSF (1982)

- Determinatio of Total Enterobacteriaceae count according to ICMSF (1978).

- Estimation of Coliform according to ICMSF (1982)

- Detection of Salmonellae: was carried according to Andrews and AOAC (1984)

- Biochemical identification of Enterobacteriaceae and Salmonellae were carried according to Cruickshank, et al. (1975) and ICMSF (1982)

- Determination of Staphylococci were done according to Cruickshank, et al. (1975) and ICMSF (1978)

- Biochemical identification of Staphylococcus aureus were carried according to (APHA, 1984)

- Total mould and yeast count were carried according to Bailey and Scott, (1978)

- Identification of mould was carried according to Raper and Fennel (1965) and Samson, et al. (1995) for genes Aspergillus and Penicillium, while other 
genera were identified according to Zycha, et al. (1969), Barnett and Hanter (1972) and Samson, et al. (1995)

- Identification of yeasts was carried according to Loder (1967)

\section{RESULTS}

Table 1: Means of $\mathrm{pH}$ of the examined treated lamb carcasses stored at $7{ }^{\circ} \mathrm{C}$

\begin{tabular}{|c|c|c|c|c|}
\hline \multirow{2}{*}{$\begin{array}{l}\text { Treatments } \\
\text { Duration }\end{array}$} & \multicolumn{4}{|c|}{ Treatment ( means \pm standard errors ) } \\
\hline & Lactic acid $1 \%$ & Lactic acid $2 \%$ & Acetic acid $1 \%$ & Acetic acid $2 \%$ \\
\hline $24 \mathrm{hr}$ chilling & $3.26 \pm 0.05 \mathrm{a}$ & $3.06 \pm 0.02 b$ & $3.36 \pm 0.02 \mathrm{a}$ & $3.06 \pm 0.02 \quad b$ \\
\hline $48 \mathrm{hr}$ & $0.50 \pm 0.03 \mathrm{ab}$ & $3.26 \pm 0.02$ & $0.02 \mathrm{a}$ & $3.32 \pm 0.04 \mathrm{ab}$ \\
\hline $72 \mathrm{hr}$ & $4.06 \pm 0.02$ & $3.54 \pm 0.02$ & $4.14 \pm 0.05 \mathrm{a}$ & $3.064 \pm 0.07 \mathrm{~b}$ \\
\hline 7day: & $5.46 \pm 0.05$ & $4.86 \pm 0.22$ & $5.52 \pm 0.09 \mathrm{a}$ & $5.10 \pm 0.05 \quad b$ \\
\hline 14 days ch & $6.08 \pm 0.04$ & $5.60 \pm 0.08$ & $6.10 \pm 0.06 \mathrm{a}$ & $5.72 \pm 0.4$ \\
\hline
\end{tabular}

Means in the same row followed by a similar letter do not differ significantly at $p=0.05$. $\mathrm{PH}$ of control samples $=5.60 \pm 0.03$.

Table 7: Incidence of Enterobacteriaceae, Staphylococcus aureus and Mould \& yeasts isolated from examined samples of treated and untreated lamb carcasses $(n=25)$

\begin{tabular}{|c|c|c|c|c|c|c|c|c|c|c|}
\hline \multirow[t]{2}{*}{ Isolates } & \multicolumn{2}{|c|}{ Control } & \multicolumn{2}{|c|}{$\begin{array}{l}\text { Lactic A } \\
1 \%\end{array}$} & \multicolumn{2}{|c|}{$\begin{array}{l}\text { Lactic A } \\
2 \%\end{array}$} & \multicolumn{2}{|c|}{$\begin{array}{l}\text { Acetic A } \\
1 \%\end{array}$} & \multicolumn{2}{|c|}{$\begin{array}{l}\text { Acetic A } \\
2 \%\end{array}$} \\
\hline & $\mathrm{N}$ & $\%$ & $\mathrm{~N}$ & $\%$ & $\mathrm{~N}$ & $\%$ & $\mathrm{~N}$ & $\%$ & $\mathrm{~N}$ & $\%$ \\
\hline Edwardsiella tarda & 0 & 0 & 0 & 0 & 0 & 0 & 1 & 4 & 0 & 0 \\
\hline Enterobacter aerogens & 3 & 12 & 1 & 4 & 0 & 0 & 0 & 0 & 1 & 4 \\
\hline Enterob.agglomerance & 0 & 0 & 1 & 4 & 0 & 0 & 1 & 4 & 0 & 0 \\
\hline E. coli & 5 & 20 & 5 & 20 & 1 & 4 & 2 & 8 & 0 & 0 \\
\hline Khlebsiella oxytoca & 0 & 0 & 1 & 4 & 0 & 0 & 0 & 0 & 0 & 0 \\
\hline $\begin{array}{l}\text { Khleb.Pumonea. } \\
\text { ozaene }\end{array}$ & 0 & 0 & 0 & 0 & 0 & 0 & 1 & 4 & 1 & 4 \\
\hline Serratea rubidea & 1 & 4 & 0 & 0 & 0 & 0 & 1 & 4 & 0 & 0 \\
\hline Salmonella enteritidis & 2 & 8 & 8 & 32 & 3 & 12 & 5 & 20 & 3 & 12 \\
\hline Staphylococcus aureus & 5 & 20 & 23 & 92 & 14 & 68 & 22 & 88 & 16 & 64 \\
\hline \multicolumn{11}{|c|}{ Isolated Moulds } \\
\hline Aspergillus flavus & 0 & 0 & 0 & 0 & 1 & 4 & 1 & 4 & 1 & 4 \\
\hline Aspergillus niger & 0 & 0 & 1 & 4 & 0 & 0 & 1 & 4 & 0 & 0 \\
\hline Fusarium & 1 & 4 & 1 & 4 & 0 & 0 & 0 & 0 & 0 & 0 \\
\hline
\end{tabular}




\begin{tabular}{|l|c|c|c|c|c|c|c|c|c|c|}
\hline Mucor spp. & 2 & 8 & 0 & 0 & 0 & 0 & 0 & 0 & 0 & 0 \\
\hline Penicillium & 2 & 8 & 2 & 8 & 3 & 12 & 6 & 24 & 2 & 8 \\
\hline
\end{tabular}

\section{DISCUSSION}

The present study aimed to assess the ability of organic acids to improve the quality of fresh lamb meat chilled at $7 \circ \mathrm{C}$ for 24,48,72 hours, 7, 14 day and freezed at $-188^{\circ} \mathrm{C}$ for one month after treatment with $1,2 \%$ of both acetic and lactic acids. The gained results could be summarized as follow. $\mathrm{pH}$ value as illustrated in Table 1 revealed decline in $\mathrm{pH}$ values as $3.06 \pm 0.05$ and $3.06 \pm 0,02$ in treated samples with $2 \%$ acetic and lactic acids. after 24 hours of chilling, gradual increase was detected with time of chilling reached its maximum at 14 day of chilling and recording $6.08 \pm 0.04$ and $5.60 \pm 0.08$ in $1,2 \%$ lactic acid. Similar results were gained in acetic acid. These results agreed with those recorded by Kim (1988) who cited significant decrease in $\mathrm{pH}$ values of pork meat sprayed by acetic acid and stored at $4{ }^{\circ} \mathrm{C}$ for 12-15 day.

Total aerobic bacterial count: Table (2) showed a mean bacterial count value of the examined control lamb sample of $3.74 \times 10^{3} \pm 3.88 \times$ $10^{2}$. After treatment with lactic acid $1 \%$ and acetic acid $1 \%$ it were $2.19 \times 10^{3} \pm 2.25 \times 10^{2}$ and $2.06 \times 10^{3} \pm 2.44 \times 10^{2}$. Using $2 \%$ lactic acid and acetic acid $2 \%$ the mean values declined to $8.8 \times 10^{2} \pm 1 \times 10^{2}$ and $8.56 \times 10^{2} \pm 1.08 \times 10^{2} \mathrm{c}$.fu $/ \mathrm{g}$. Successive decline in mean values of aerobic bacterial count with time of chilling after treatment reached in the $7^{\text {th }}$ day to $6.38 \times 10^{2} \pm 0.53 \times 10^{2}$ and $5.53 \times 10^{2} \pm 0.51 \times 10^{2}$ and $5.96 \times 10^{2} \pm 0.51 \times 10^{2}$ and $5.13 \times 10^{2} \pm 0.5 \times 10^{2} \mathrm{cfu} / \mathrm{g}$ in lactic acid $1 \& .2 \%$ and acetic acid 1 and $2 \%$ respectively. While after 14day of chilling post treatment, slight increase was detected. The reduction percent of total aerobic bacterial count as illustrated in Table 3 revealed that, the best reduction percentages were 70.87, 64.09, 71.07and $60.54 \%$ at $7^{\text {th }}$ day chilling of lamb meat samples with lactic acid $1 \%, 2 \%$ and acetic acid respectively this could be attributed to the destructive effect of these acids on different microbes in addition to the longer acidic phase which started after bleeding of animal. Nearly similar results were reported by Anderson and Marshall (1989), Mendonca, et al. (1989) Gauthier and Jacquet (1991), Anderson et al, (1992), Zerby et al. (1999) and Mahmoud (2004) all have agreed with reduction in total aerobic 
count. The freezing of treated samples for one month revealed the reduction percent varied from 62.37 to 62.5357 .96 and $57.38 \%$ respectively with using $1 \& 2 \%$ lactic acid and $1 \& 2 \%$ acetic acid. That reduction percent could be attributed to the acid treatment effect, in addition to the effect of freezing on different microbes. Nearly similar results were reported by Arjyapitipum et al. (1999).

Total psychrophilic bacterial count: Table 2 showed that, the mean value of total psychrophilic bacterial count (cfu/g) was $2.06 \times 10^{3} \pm 2.85$ $\times 10^{2}$. Treatment with lactic acid $1 \% \& 2 \%$ and acetic acid $1 \% \& 2 \%$ revealed means as $1.53 \times 10^{3} \pm 1.67 \times 10^{2}, 1.2 \times 10^{3} \pm 1.5 \times 10^{2}$ and $1.46 \times 10^{3} \pm 1.82 \times 10^{2}$ and $1.02 \times 10^{3} \pm 1.21 \times 10^{2} \mathrm{cfu} / \mathrm{g}$ respectively. The mean counts gradually decreased as after 7 days of chilling reached $7.72 \times 10^{2} \pm 0.65 \times 10^{2}, 6.8 \times 10^{2} \pm 0.66 \times 10^{2}$ and $6.81 \times 10^{2} \pm 0.72 \times$ $10^{2}$ and $6.32 \times 10^{2} \pm 0.64 \times 10^{2} \mathrm{cfu} / \mathrm{g}$ respectively, more decline was recorded after 14 day of chilling of meat samples as shown in Table 2. That significant decrease of total phychrophilic count at $\mathrm{p}=0.05$ agreed with those reported by Andersen and Marchall (1989), Dorsa et al. (1998) and Lee et al. (1998).

Result in Table 4 denote that the reduction percent of psychrophilic count showed the best reduction percent at the $7^{\text {th }}$ day of chilling of treated lamb meat samples as 49.54, 43.33, 53.36 and $38.04 \%$. Nearly similar result were reported by Anderson and Marshall (1989), Dickson, (1991, and Ariyapitipum et al. (1999).

Total Coliform count Table 4 Showed excessive decline with the time of storage at chilling after treatment with $1 \%, 2 \%$ lactic and acetic acids where in control the mean value was $1.53 \times 10^{3} \pm 1.82 \times 10^{2} \mathrm{cfu} / \mathrm{g}$. After treatment means declined to $9.83 \times 10^{2} \pm 1.31 \times 10^{2}, 6.46 \times 10^{2} \pm 0.99 \times$ $10^{2}, 1.02 \times 10^{2} \pm 1.41 \times 10^{2}$ and $4.6 \times 10^{2} \pm 0.8410^{2} \mathrm{cfu} / \mathrm{g}$ respectively after 14 day of chilling post treated it reached to $4.63 \times 10^{2} \pm 0.48 \times 10^{2}$, $3.93 \times 10^{2} \pm 0.43 \times 10^{2}$ and $4.34 \times 10^{2} \pm 0.43 \times 10^{2}, 3.46 \times 10^{2} \pm 0.43 \times$ $10^{2} \mathrm{cfu} / \mathrm{g}$. Nearly similar results were recorded by Anderson and Marshall (1989), Castillo, et al. (1998), Dorsa et al. (1998) and Zerby et al. (1999)

The reduction percent as illustrated in Tabte 5 denoted that, at $7^{\text {th }}$ day of chilling the reduction rat of the treated samples reached 73.65, $69.04,77.84$ and $68.59 \%$. after application of lactic acid and acetic acid $1 \% \& 2 \%$ respectively, while in freezing the reduction percent was 53.51, $45.51,63.72$ and $45.00 \%$, respectively. Similar results were recorded by Anderson and Marshall (1989), Cutter and Siragusa (1994), Cabedo et al. (1996) and Ramirez, et al. (2001). 
Total Enterobacteriaceae count: Table 4 revealed that, the mean value of control non treated sample was $2 . \times 10^{3} \pm 2.55 \times 10^{3}$ after treatment with $1 \%, 2 \%$ lactic acid acetic acid the reduction in mean values gradually increase tell $7^{\text {th }}$ day reached $3.69 \times 10^{2} \pm 0.43 \times 10^{2}, 3.25 \times 10^{2}$ $\pm 0.4 \times 10^{2} \cdot 3.58 \times 10^{2} \pm 0.4 \times 10^{2}$ and $2.97 \times 10^{2} \pm 0.38 \times 10^{2}$. The higher concentration $2 \%$ acetic acid showed significantly $(\mathrm{p}<0.05)$ lower count compared to other acid treatment. Nearly similar results were recorded by Anderson et al. (1992) and Ariyapitipun et al. (1999). In the $7^{\text {th }}$ day of chilling. The highest reduction percent $68.06,65.24$, 71.81 , and $64.77 \%$ were recorded as in Table 5. Similar results reported by Mendonca, et al. (1989) and Anderson et al. (1992)

Table 7 revealed that, the isolated Enterobacteriaceae from the examined lamb carcasses at variable percentages were Edwardsiella tarda, Enterobacter arerogenes, Enterobacter agglornerans, Escherichia coli., Klebsiella oxytocea, Klebsiella pneurnoniae sub.ozaene and Serratia rubide in the control and treated samples as well as during. Some isolates were found in control samples as well as in treated one during chilling and freezing.

The presence of coliforms in the food pointed at the unsanitary condition of slaughter and processing plants as they are indicative of fecal pollution either from workers, lamb or all equipment kept in touch with them. Efforts should be directed towards thorough cleaning and sanitizing all equipment come in contact with lamb carcasses and workers, thorough cleaning of lamb carcasses and hygienic measures should be adopted during different stages.

Salmonella count: Table 6 shows the mean count of 25 examined lamb carcasses for salmonella as control was $4.8 \times 10^{2} \pm 3.2 \times 10^{2}$ After treatment with lactic acid $1 \%$ and $2 \%$, ctic acid $1 \& 2 \%$ the means of salmonella count gradually decreased till reach $0.6 \times 10^{2} \pm 0.00,0.2 \times$ $10^{2} \pm 0.00,0.6 \times 10^{2} \pm 0.2 \times 10^{2}$ and $0.4 \times 10^{2} \pm 0.00$ respectively. After 72 hour of treatment reduction rate became $76.92,83.33,78.57$ and $69.23 \%$. Nearly similar results were reported by Anderson and Marchall, (1990), Anderson et al. (1992), Conner, et al. (1997) and Zerby et al. (1998)

Table 7 denote the identified Salmonella enteritidis isolated from the examined lamb carcasses incidentally appeared with its percentage as $2(8 \%)$ in the control, while in lactic acid $(1 \%$ and $2 \%)$ treated samples, the percentages were $8(32 \%)$ and $3(12 \%)$, 
respectively. In acetic acid (1\% and $2 \%)$ treated samples it was shown as $5(20 \%)$ and $3(12 \%)$.

Salmonella remains one of the most common causes of bacterial food poisoning and associated with the consumption of meat. These organisms colonies the alimentary tract and excreted in the feces by infected animals thereby the human food chain. Salmonella typhimurium and Salmonella enteritidis are numerically the predominant serotypes affecting meat causing human infection through consumption of meat.

Staphylococcus aureus count: Table 6 shows a mean values of $2.44 \pm$ $0.67 \times 10^{2}$ in control examined. After treating samples with $1 \%$ \& $2 \%$ lactic acid and acetic acid means were gradually decreased with continuous chilling till $7^{\text {th }}$ day reached to $0.8 \times 10^{2} \pm 0.22 \times 10^{2,} 0.45 \times$ $10^{2} \pm 0.19 \times 10^{2}, 0.6 \times 10^{2} \pm 0.22 \times 10^{2}$ and $0.50 \times 10^{2} \pm 0.3 \times 10^{2} \mathrm{cfu} / \mathrm{g}$, respectively. That highest reduction forms $42.86,60.86,59.46,33.33 \%$ as well as samples treated with $1 \% \& 2 \%$ lactic acid and $1 \% \& 2 \%$ acetic acid after freezing the treated samples the reduction percents as 7.14, 64.91, 55.41 and 60\% respectively Table(3) Nearly similar results were reported by Mahmoud (2004)

Staphylococcus aureus: Could be isolated from the same examined samples as $23(92 \%)$ lactic acid 1\%, 14 (68\%) lactic acid 2\%, 22 $(88 \%)$. acetic acid $1 \%$, and $16(64 \%)$ acetic acid $2 \%$.

Staphylococci are widespread in nature; they are members of the normal bacterial flora of the skin and mucous membranes. Staphylococcus aureus was frequently involved in case of mastitis and suppurative infections. Hence contamination of food with the organism mostly occurs due to sanitary neglected precautions during production or processing. When conditiens are favorable for growth and multiplication of the organism in food, the enterotoxins are produced and consequently the food is likely to be dangerous. Enterotoxigenic Staphylococcus aureus has been implicated in several food poisoning outbreaks from consumption of lamb carcasses and its products (Beckers, 1982).

Total mould and yeast count: Table 6 revealed a mean of $2.93 \times 10^{2} \pm$ $0.3 \times 10^{2} \mathrm{cfu} / \mathrm{g}$, in control sample. When lactic acid $1 \% \& 2 \%$, acetic acid $1 \%, 2 \%$ were applied the mean count of mould and yeasts continued to decline with time of chilling reached to $0.77 \times 10^{2} \pm 0.08 \times 10^{2}, 0.58 \times$ $10^{2} \pm 0.11 \times 10^{2}, 0.72 \times 10^{2} \pm 0.07 \times 10^{2}$ and $0.50 \times 10^{2} \pm 0.06 \times 10^{2}$ respectively after 72 hour of chilling, the reduction percent of yeasts \&mould as in Table 5 recorded as 56.74, 52.07, 52.94 and 39.02\% 
respectively. Nearly similar results were recorded by Samelies et al. (2002). A slight rising of mean values was recorded after 7 and 14 day of chilling. That could be attributed to optimal $\mathrm{pH}$ of mould, yeast growth as recorded by Samelis et al. (2002) who mentioned that acids containing washings were selective for growth of yeast. Slight decline recorded after freezing for one month. This was attributed to that mould and yeast grow at chilling and freezing as reported by Samelis et al. (2002). Table 7 also reveals that Aspergillus flavus, Aspergillus niger, Fusarium, Mucor and Penicillium could be isolated from examined treated lamb samples at variable percentages. From the public health point of view, species of Aspergillus may induce pulmonary aspergillosis and allergy, and skin infection (Al-Doory, 1980 and Washington, 1981) for meat handlers. Penicillium spp. may induce pulmonary infection (Washington, 1981) Mucor and Rhizopus spp. are prevalent in food and may induce infection in lungs, gastrointestinal tract and skin (Al-Doory, 1980 and Washingto, 1981).

Proteolytic and lipolytic bacterial counts: Both of proteolytic and lipolytic bacterial count when applied lactic acid 1 and $2 \%$, acetic acid $1 \& 2 \%$ revealed reduction in their mean count. The highest reduction percent was apparently with using lactic acid $2 \%$ as $42.26 \%$ and $59.87 \%$ for proteolyic and lipolytic bacterea, while that of acetic acid $2 \%$ was 38.65 and $60.88 \%$ respectively. These result agreed with that reported by Gill and Newton (1982) Anderson et al. (1988) Katoh et al. (1991) and Hassan (2001)

The isolated strains of economic importance as they are food spoilage microorganisms beside they are of public health hazard, especially E. coli which causes acute infection to adult. It also causes infections of the urinary tract (Cruickshank, et al., 1975).

\section{REFERANCES}

Al-Doory, $\quad Y$. (1980): Laboratory Procedures in Clinical Microbiology. Springer Verlag, New York, Inc.

Anderson, M.E.H.; Huff, E.; Naumann, H.D. and Marshall, R.T. (1988): Counts of six types of bacteria on lamb carcasses dipped or sprayed with acetic acid at $25{ }^{\circ} \mathrm{C}$ or $55{ }^{\circ} \mathrm{C}$ and stored vacuum packaged at $0{ }^{\circ} \mathrm{C}$. J. Food Prot., 51: 874877. 
Anderson, M.E.H.; Marshall, R.T.; Stringer, W.C. and Naumann, H.D. (1977): Combined and individual effects of washing and sanitizing on bacterial counts of meat - a model system. J. Food Prot., 40; 668-670.

Anderson, M.E. and Marshall, R.T. (1989): Interaction of concentration and temperature of acetic acid solution on reduction of various species of microorganisms on beef surfaces. J. Food Prot., 52: 312-315.

Anderson, M.E. and Marshall, R.T. (1990): Reducing microbial population on beef tissues concentration and temperature of lactic acid. J. Food Safety, 10: 181-190.

Anderson, M.E.; Marshall, R.T. and Dickson, J.S. (1992): Efficacies of acetic lactic and two mixed acids in reducing number of bacteria on surfaces of lean meat. J. Food Safetv 12(2): 139-i47.

Andrews, W.F. and AOAC (1984): Isolation and identification of Salmonella species. In: Food and Drug Administration, Division of Microbiology Center for Food Safety. Bacteriological Analytical Manual, 6t" edition. Published by Association of Official Analytical Chemists, Arlington, Virginia, 22201-3301 USA. Chapter 7.

Anonymous (1982): Rules and regulations. Fed. Regist. 47:184 APHA (American Public Health Association) (1984): Compendium of Methods for Micro biological Examination of Foods. $2^{\circ} \mathrm{d}$ Ed., American Public Health Association, Washington, DC.

Ariyapitipun, T.; Mustapha, A. and Larke, D. (1999): Microbial shelf-life determination of vacuum-packaged fresh treated with polylactic acid, lactic acid and nisin solution. J. Food Prot., 62: 913.

Bailey, W.R. and Scott, E.G. (1978): Diagnostic microbiology, A Textbook for the Isolation and

Barnnett, H.L. and Hunter, B.B. (1972): Illustrated Genera of Imperfect Fungi. $2^{\text {nd }}$ ed., Burgess Publishing Company.

Beckers, H.J. (1982): Incidence of foodborne disease in the Netherlands and annual summary 1979. J. Food Prot., 45(14): 13-36.

Cabedo, L.; Sofos, J.N. and Smith, G.C. (1996): Removal of bacteria from beef tissues by spray washing after different times of exposure to fecal material 
. J. Food Prot. 59(12)1284-1287.

Castillo, A.L.; Lucia, M.; Goodson, K.J.; Savell, J.W. and Acuff, G.R. (1998): Comparison of water wash, trimming, and combined hot water and lactic acid treatments for reducing bacteria of fecal origin on beef carcasses. J. Food Prot., 61:823-828.

Castillo, A.L.; Lucia, M.; Merado, I. and Acuff, G.R. (2001): Inplant evaluation of a lactic acid treatment for reduction of bacteria on chilled beef carcasses J. food prot. 64 (5): 738-740.

Conner, D.E.; Kotrola, J.S.; Mikel, W.B. and Tamblyn, K.C. (1997): Effect of aceticlactic acid treatment applied to beef trim on populations of Escherichia coli 0157:H7 and Listeria monocytogenes in ground beef. Journal of Food Protection, 60(12), 1560-1563.

Cruickshank, R.: Duouid, J. R.; Marmion, B. D. and swain, R. H. A. (1970-1975): Medical Microbiology. The practice of microbiology. VIII $11^{\text {th }}$ and $12^{\text {th }}$ Ed., Churchill Livingstone Edinburgh.

Cutter, C.N. and Siragusa, G.R. (1994): Efficacy of organic acids against Escherichia coli 0157:H7 attached to beef carcass tissue using pilot scale model carcass washer. J. Food Protect. 57: 97-103.

Davis,M.H.;Hadley,M.J.;Stosic,P.J.;Webster,S.D.(2000): Product ion of factors that influence the hygienic condition of finished beef cattle J.Vet.Rec.14,179

Diclcson, J. S. (1991): Control of Salmonella ryphimurium, Listeria monocytogenes and Escherichia coli $0157: \mathrm{H} 7$ on beef in a model spray chilling system. J. Food Sci. 56:191 193.

Dickson, J. S. and Anderson, M. E.(1991): Control of Salmonella on beef tissue surfaces in a model system by pre- and postevisceration washing and sanitizing, w1th) and without spray chilling. J. Food Protect. 54, 514-515.

Dickens, J. A.; Lyon, B. G.; Whittemore, A. D. and Lyon, C. E.(1994): The effect of an acetic acid dip on carcass appearance, microbiological quality, and cooked breast meat texture and flavor. Poultry Science 73: 576-581.

Dorsa, W. J.; Cutter, C. N.; Siragusa, $\mathbf{G}_{(1 \mathbf{R})}$ (1998):Long-term effect of alkaline, organic acid, or hot water washes on the 
microbial profile of refrigerated beef contaminated with bacteria pathogens after washing. Journal of Food Protection 61 (3) 300 -3 ) 06

Fatema-Ali ,H.(2001) Evaluation of the sanitary measures adopted in a municipality abattoir

Ph.D. Vet.Sci., Fac.Vet.Med. Beni Suef, Cairo Univ.

Gauthier, M ., and jacquet, B. ( 1991 ) : Decontmination des viands triees de porc destinees a la transformation par les acides organiques. Viandes prod. Carnes. 12:131 -135 .

Gill , c.o. and Newton , K .G. (1982) : Effect of lactic acid concentrtion on growth on meat of gram - nagative psychrotrophs from a meatworks. Appl. Environ. Microboil., 43: 284 - 288 .

Gorman,B.M.;Kochevar,S.L.;Sofos,J.N.;Morgan,J.B.;Schmedt,G.R. and Smith,G.C.(1997)

Changes on beef adipose tissues following decontamination with chemical solutions or water at $35 \dot{\mathrm{C}}$ and $74 . \mathrm{C}$ J.Muscl Food 8:185-197

Hardin,M.D.;Acuff,G.R.;Lucia,L.M.;Oman,J.S.andSavell,J.W.(1995

) Comparison of methods for decontamination from beef carcass surface J.Food protect.58:268-374

Hassan, F. M. (2001): Evaluation of the sanitary measures adopted in a municipality abattoirs.

Thesis ph. D.Fac. Vet. Med., Cairo Univ .

ICMSF (International Commission on Microbiological Specification of Foods) (1978): Microorganisms ecology of food. University of Toronto Press, Toronto, Ontario, Canada.

ICMSF (International Commission on Microbiological Specification of Foods) (1982): Microorganisms in food 1. Salmonellae. $2^{\text {nd }}$ Ed. University of Toronto Press, Toronto, PP.201-218.

Katoh, K.; Nakamura, M.; Usagawa, T. (1991): The curing of pork with organic acid containing reduced-salt brine. Animal Science and Technology 62 (2) 161-168

Kim, D.G. (1988): Effects of acetic acid on microbiological and physicochemical properties of fresh pork. Journal of the Korean Society of Food and Nutrition 17 (3) 215-219

Lee, S. H.; Seung, S. K; Kim, S. M.; Kim, D. K.; Jo, O. K. and Jeong, Y. S. (1998): Effects of organic acids and vacuum packaging on shelf life of Hanwoo beef. Korean Journal of Animal Science 40(3)261-268. 
Lodder, J, and Kreger, Van Rij, N. J. W. (1967): The Yeast, a taxonomic study. North Holland Publ. Co., Amsterdam.

Leuck,E.(1980): Antimicrobial food additives Springer Verlag, Neo York

Mahmoud,M.A.(2004) : Sanitary evaluation and reduction trials for surfaces microbial contamination of sheep carcasses at Mansoura abbatoir M.V.Sc.Thesis Fac.Vet.Med.Mansoura Univ.

Mendonca, A. F.; Molins, R. A. A.; Walker, H. W. (1989): Microbiological, chemical, and' physical changes in fresh, vacuum-packaged pork treated with organic acids and salts Journal of Food Science 54 (1) 18-21.

Podolak,R.k.J.F.Zayas,C.L.,Katner and D.y.c.fung (1996) Reduction of bacterial population on vacuum-packaged ground beef patties with fumaric and lactic acids.J.Food Prot.59-1037-1040

Ramirez, A. J.; Acuff, G. R.; Lucia, L. M. and Savell, J. W. (2001): Lactic acid and trisodium phosphate treatment of lamb breast to reduce bacterial contamination. J. Food Prot. 64, 1439-1441.

Raper, R. K. B and Fennel, D, I. (1965): The genus Aspergillus. Williams and Wilkins, Baltimore. Cited after Khalil, R (1995): M. V. Sc. Thesis, Fac. Vet. Med., Alex., Univ.

Samelis J, Sofos JN, Kendall PA, Smith GC. (2002): Effect of acid adaptation on survival of Escherichia coli 0157:H7 in meat decontamination washing fluids and potential effects of organic acid interventions on the microbial ecology of the meat plant environment. J Food Prot., Jan; 65(1): 33-40.

Samson, R. A.; Hockstra, E. S.; Frisvad, J. C. and Filtenburge, D. (1995): Introduction to food borne fujgi. $4 \mathrm{t}$ "'Ed., Central Bureau voor Schimmel Culture, Baan Delft. ( 16 )

Printed by Prison \& Looyen Wageningen, The Netherlands.

Washington, J.A. (1981): Laboratory Medical Mycology. Lea \& Febiger.

Zerby, H.N.; Murphree, R.; Belk, K.E.; Sofos, J.N.; Schmidt, G.R.; IIardin, M.W.; Lloyd, W.L. and Smith, G.C. (1998): Intervention Strategies for Reducing Microbiological Contamination On Pork Variety Meats. Final Report to the U.S. Meat Export federation and to the National Pork Producers Council.

Zerby, H.N.; Belk, K.E.: Hardin, M.; Sofos. J.N. and Smith, G.C. (1999): Levels of microbiological contamination of pork 
carcasses during slaughter. Annual Meeting. International Association of Milk, Food and Environmental Sanitarians, 86:T1 1.

Zycha, H.; Siepmann, R. and Linnnemann, G. (1969): Mucorales, eine Beschrelbung alter Gattungen und Arten dieser Pilzgruppe. D. 3301 Lehre J. Gramer. 
Table (5) Reduction percentages of total coliform,

Enterobacteriaceae, Salmonellae

and Mould \& Yeast count of examined treated lamb carcasses

\begin{tabular}{|c||c|c|c|c||c|c|c|c||c}
\hline \multicolumn{1}{|c||}{ Treat. } & \multicolumn{4}{|c|}{ Lactic acid 1\% } & \multicolumn{3}{c||}{ Lactic acid 2\% } & \\
\hline \hline Isolate & Coli. & Ent. & Salm. & $\begin{array}{c}\text { Yeast } \\
\text { \&Mold }\end{array}$ & Coli. & Ent. & Salm. & $\begin{array}{c}\text { Yeast } \\
\text { Mold }\end{array}$ & C \\
\hline \hline Fresh & 35.75 & 38.00 & 45.83 & 39.25 & 57.78 & 53.25 & 75.0 & 58.70 & 33 \\
\hline $\mathbf{2 4}$ h & 35.20 & 22.98 & 56.54 & 30.90 & 29.72 & 32.41 & 41.67 & 42.98 & 38 \\
\hline $\mathbf{4 8 ~ h}$ & 48.94 & 45.24 & 65.38 & 42.13 & 37.77 & 51.23 & 60.83 & 47.93 & 48 \\
\hline $\mathbf{7 2 ~ h}$ & 60.73 & 55.89 & 76.37 & 56.74 & 60.00 & 83.33 & 61.86 & 52.07 & 57 \\
\hline $\mathbf{7 ~ d ~}$ & 73.65 & 68.06 & - & 33.71 & 69.04 & 65.24 & - & 46.28 & 77 \\
\hline $\mathbf{1 4 ~ d}$ & 52.90 & 52.74 & - & 16.83 & 39.16 & 47.59 & - & 17.36 & 57 \\
\hline Freezing & 53.51 & 53.06 & - & 26.97 & 45.51 & 55.72 & - & 29.75 & 63 \\
\hline
\end{tabular}

The reduction percent was the deviation of treated means relative to control mean in the fresh state in chilling and freezing state

It was the deviation of treated means relative to the treatment means in fresh state

Coli=Coliform

Ent. .= Enterobactereaceae

Salm. = Salmonellae

Table (3) Reduction percentages of total aerobic, psychrophilic and .

Staph. aureus count

of the examined treated lamb carcasses $(n=25)$

\begin{tabular}{|c|c|c|c|c|c|c|}
\hline Treat & \multicolumn{3}{|c|}{ Lactic acid 1\% } & \multicolumn{3}{|c|}{ Lactic acid $2 \%$} \\
\hline & aerobic & psychro. & Staph. & aerobic & psychro. & Staph. \\
\hline
\end{tabular}




\begin{tabular}{|c|c|c|c|c|c|c|c|}
\hline Fresh & 41.44 & 25.73 & 42.62 & 58.82 & 41.75 & 53.28 & \\
\hline 24 h . Chil & 37.44 & 17.65 & $+22.14^{*}$ & 42.86 & 14.17 & $+10.53^{*}$ & \\
\hline 48 h. Chil & 53.88 & 38.59 & 2.868 & 52.86 & 41.17 & 40.35 & \\
\hline 72 h. Chil & 48.40 & 44.12 & 37.14 & 61.10 & 45.33 & 3.51 & \\
\hline 7 d. Chil & 70.87 & 49.45 & 42.86 & 64.09 & 43.33 & 60.53 & \\
\hline 14 d. Chil & 57.70 & 33.33 & 7.14 & 41.10 & 23.25 & 29.28 & \\
\hline Freezing & 62.37 & 29.4 & 7.14 & 62.53 & 15.00 & 64.91 & \\
\hline
\end{tabular}

The reduction percent was the deviation of treated means relative to control mean in the fresh state in chilling and freezing state

( It was the deviation of treated means relative to the treatment means in fresh state)

Chil $=$ Chilling $\quad$ aerob.$=$ aerobic $\quad$ Psychro $=$ Psychrophilic

Table (2) Means of total aerobic and total psychrphilic bacterial counts ( $\mathrm{cfu} / \mathrm{g}$ ) of the examined lamb carcasses before and after application of acid treatment $(n=25)$

\section{Treatments ( Means \pm standard errors )}

\begin{tabular}{|c|c|c|c|c|c|c|}
\hline Lactic & cid $1 \%$ & Lactic & idd $2 \%$ & Aceti & cid $1 \%$ & \\
\hline aerobic & Total psychr & Total aerobic & Total psychr & Total aerobic & Total psychr & \\
\hline
\end{tabular}




\begin{tabular}{l|l|l|l|l|l|l}
\hline \hline$\times 10^{3} \pm$ & $1.25 \times 10^{3} \pm$ & $1.54 \times 10^{3} \pm$ & $1.2 \times 10^{3} \pm$ & $2.06 \times 10^{3} \pm$ & $1.46 \times 10^{3} \pm$ & $1.3 \times$ \\
$\times 10^{2} \mathbf{a}$ & $1.67 \times 10^{2} \mathbf{a}$ & $2 \times 10^{2} \mathbf{b c}$ & $1.5 \times 10^{2} \mathbf{a b}$ & $2.44 \times 10^{2} \mathbf{a b}$ & $1.82 \times 10^{2} \mathbf{c}$ & 1.89 \\
\hline$\times 10^{3} \pm$ & $1.26 \times 10^{3} \pm$ & $8.8 \times 10^{2} \pm 1$ & $1.03 \times 10^{3} \pm$ & $1.42 \times 10^{3} \pm$ & $1.11 \times 10^{2} \pm$ & $8.56 \times 1$ \\
$\times 10^{2} \mathbf{a}$ & $1.02 \times 10^{2} \mathbf{a}$ & $\times 10^{2} \mathbf{b}$ & $0.92 \times 10^{2} \mathbf{a}$ & $1.34 \times 10^{2} \mathbf{a}$ & $0.86 \times 10^{2} \mathbf{a}$ & 1.08 \\
\hline$\times 10^{3} \pm$ & $9.34 \times 10^{2} \pm$ & $7.26 \times 10^{2} \pm$ & $7.06 \times 10^{2} \pm$ & $1.03 \times 10^{3} \pm$ & $9.2 \times 10^{2} \pm$ & $7.15 \times$ \\
$10^{2} \mathbf{a}$ & $0.74 \times 10^{2} \mathbf{a}$ & $0.93 \times 10^{2} \mathbf{b}$ & $0.7 \times 10^{2} \mathbf{a}$ & $1.31 \times 10^{2} \mathbf{a}$ & $0.82 \times 10^{2} \mathbf{a}$ & 1.08 \\
\hline$\times 10^{3} \pm$ & $8.55 \times 10^{2} \pm$ & $5.99 \times 10^{2} \pm$ & $6.56 \times 10^{2} \pm$ & $7.92 \times 10^{2} \pm$ & $7.8 \times 10^{2} \pm$ & 5.57 \\
$\times 10^{2} \mathbf{a}$ & $0.84 \times 10^{2} \mathbf{a}$ & $0.75 \times 10^{2} \mathbf{b c}$ & $0.77 \times 10^{2} \mathbf{b}$ & $0.92 \times 10^{2} \mathbf{a b}$ & $0.89 \times 10^{2} \mathbf{a}$ & 0.76 \\
\hline$\times 10^{2} \pm$ & $7.72 \times 10^{2} \pm$ & $5.53 \times 10^{2} \pm$ & $6.8 \times 10^{2} \pm$ & $5.96 \times 10^{2} \pm$ & $6.81 \times 10^{2} \pm$ & 5.13 \\
$\times 10^{2} \mathbf{a}$ & $0.65 \times 10^{2} \mathbf{a}$ & $0.51 \times 10^{2} \mathbf{a}$ & $0.66 \times 10^{2} \mathbf{a}$ & $0.51 \times 10^{2} \mathbf{a}$ & $0.72 \times 10^{2} \mathbf{a}$ & $0.5 \times$ \\
\hline$\times 10^{2} \pm$ & $1.02 \times 10^{2} \pm$ & $9.07 \times 10^{2} \pm$ & $9.21 \times 10^{2} \pm$ & $8.85 \times 10^{2} \pm$ & $9.16 \times 10^{2} \pm$ & $7.89 \times$ \\
$\times 10^{2} \mathbf{a}$ & $0.5910^{2} \mathbf{a}$ & $0.61 \times 10^{2} \mathbf{a}$ & $0.95 \times 10^{2} \mathbf{a}$ & $0.77 \times 10^{2} \mathbf{a}$ & $0.68 \times 10^{2} \mathbf{a}$ & 0.72 \\
\hline$\times 10^{2} \pm$ & $1.08 \times 10^{2} \pm$ & $5.77 \times 10^{2} \pm$ & $1.02 \times 10^{3} \pm$ & $6.66 \times 10^{2} \pm$ & $1.07 \times 10^{2} \pm$ & 5.54 \\
$\times 10^{2} \mathbf{a}$ & $1.7 \times 10^{2} \mathbf{a}$ & $0.94 \times 10^{2} \mathbf{a}$ & $1.3 \times 10^{2} \mathbf{a}$ & $1.2 \times 10^{2} \mathbf{a}$ & $1.44 \times 10^{2} \mathbf{a}$ & 0.95 \\
\hline \hline
\end{tabular}

Means in the same raw followed by same letters do not differ

significantly at $\mathrm{p}=0.05$ within each of aerobic and Psychrphilic counts

Mean value of control samples in total aerobic bacterial count $=3.74 \times$

$10^{3} \pm 2.88 \times 10^{2}$

Mean value of control samples in total Psychrphilic bacterial count $=$ $2.06 \times 10^{3} \pm 2.85 \times 10^{2}$

Table (4) Statistical analytical results of means of total coliform (M.P.N/g) \&Enterobacteriaceae count (cfu/g) of examined lamb carcasses before and after application of acid treatment $(n=25)$

\section{Treatments ( Means \pm standard errors )}

\begin{tabular}{l|l|l|l|l|l|l}
\hline \multicolumn{2}{c|}{ Lactic acid 1\% } & \multicolumn{2}{c|}{ Lactic acid 2\% } & \multicolumn{2}{c|}{ Acetic acid 1\% } & \\
\hline form & enterob & coliform & Enterob & coliform & enterob & colifo \\
\hline $3 \times 10^{2} \pm$ & $1.24 \times 10^{3} \pm$ & $6.46 \times 10^{2} \pm$ & $9.33 \times 10^{2} \pm$ & $1.02 \times 10^{2} \pm$ & $1.27 \times 10^{2} \pm$ & $6.4 \times$ \\
\hline \hline
\end{tabular}




\begin{tabular}{c|l|l|l|l|l|l}
\hline \hline$\times 10^{2} \mathbf{a}$ & $1.7 \times 10^{2} \mathbf{a}$ & $0.99 \times 10^{2} \mathbf{b}$ & $1.59 \times 10^{2} \mathbf{a b}$ & $1.41 \times 10^{2} \mathbf{a}$ & $1.94 \times 10^{2} \mathbf{a}$ & 0.84 \\
\hline \hline$\times 10^{2} \pm$ & $9.55 \times 10^{2} \pm$ & $4.54 \times 10^{2} \pm$ & $6.36 \times 10^{2} \pm 1$ & $6.31 \times 10^{2} \pm$ & $9.72 \times 10^{2} \pm$ & $4.47 \times$ \\
$\times 10^{2} \mathbf{a}$ & $1.55 \times 10^{2} \mathbf{a}$ & $0.77 \times 10^{2} \mathbf{a}$ & $\times 10^{2} \mathbf{b}$ & $0.86 \times 10^{2} \mathbf{a}$ & $1.69 \times 10^{2} \mathbf{b}$ & 0.68 \\
\hline $2 \times 10^{2} \pm$ & $6.79 \times 10^{2} \pm$ & $4.02 \times 10^{2} \pm$ & $4.56 \times 10^{2} \pm$ & $5.21 \times 10^{3} \pm$ & $6.5 \times 10^{2} \pm$ & $3.83 \times$ \\
$7 \times 10^{2} \mathbf{a}$ & $0.87 \times 10^{2} \mathbf{a}$ & $0.87 \times 10^{2} \mathbf{a}$ & $0.71 \times 10^{2} \mathbf{b c}$ & $0.99 \times 10^{2} \mathbf{a}$ & $0.94 \times 10^{2} \mathbf{a b}$ & 0.85 \\
\hline $5 \times 10^{2} \pm$ & $5.47 \times 10^{2} \pm$ & $3.06 \times 10^{2} \pm$ & $3.74 \times 10^{2} \pm$ & $3.89 \times 10^{2} \pm$ & $5.46 \times 10^{2} \pm$ & $2.97 \times$ \\
$5 \times 10^{2} \mathbf{a}$ & $0.73 \times 10^{2} \mathbf{a}$ & $0.58 \times 10^{2} \mathbf{a}$ & $0.65 \times 10^{2} \mathbf{b}$ & $0.66 \times 10^{2} \mathbf{b}$ & $0.87 \times 10^{2} \mathbf{a b}$ & 0.63 \\
\hline $5 \times 10^{2} \pm$ & $3.69 \times 10^{2} \pm$ & $2 \times 10^{2} \pm$ & $3.25 \times 10^{2} \pm$ & $2.26 \times 10^{2} \pm$ & $3.58 \times 10^{2} \pm$ & $2.01 \times$ \\
$7 \times 10^{2} \mathbf{a}$ & $0.43 \times 10^{2} \mathbf{a}$ & $0.34 \times 10^{2} \mathbf{a}$ & $0.4 \times 10^{2} \mathbf{a}$ & $0.35 \times 10^{2} \mathbf{a}$ & $0.4 \times 10^{2} \mathbf{a}$ & 0.34 \\
\hline $3 \times 10^{2} \pm$ & $5.86 \times 10^{2} \pm$ & $3.93 \times 10^{2} \pm$ & $4.9 \times 10^{2} \pm$ & $4.34 \times 10^{2} \pm$ & $5.34 \times 10^{2} \pm$ & $3.46 \times$ \\
$3 \times 10^{2} \mathbf{a}$ & $0.47 \times 10^{2} \mathbf{a}$ & $0.43 \times 10^{2} \mathbf{a}$ & $0.45 \times 10^{2} \mathbf{a}$ & $0.43 \times 10^{2} \mathbf{a}$ & $0.47 \times 10^{2} \mathbf{b}$ & 0.43 \\
\hline $7 \times 10^{2} \pm$ & $5.82 \times 10^{2} \pm$ & $3.52 \times 10^{2} \pm$ & $4.14 \times 10^{2} \pm$ & $3.7 \times 10^{2} \pm$ & $5.7 \times 10^{2} \pm$ & 3.52 \\
$\pm \times 10^{2} \mathbf{a}$ & $1.28 \times 10^{2} \mathbf{a}$ & $0.94 \times 10^{2} \mathbf{a}$ & $1.18 \times 10^{2} \mathbf{a}$ & $0.8 \times 10^{2} \mathbf{a}$ & $1.35 \times 10^{2} \mathbf{a}$ & 0.94 \\
\hline \hline
\end{tabular}

Enterob $=$ Enterobacteriaceae

Means in the same raw followed by same letters do not differ

significantly at $\mathrm{p}=0.05$ within each of Coliform and Enterobacteriaceae count

Mean value of control samples in total Coliform count $=1.53 \times 10^{3} \pm$ $1.82 \times 10^{2}$

Mean value of control samples in total Enterobacteriaceae count $=2.00$ $\times 10^{3} \pm 2.55 \times 10^{2}$

Table (6) Statistical analytical results of means of total Salmonellae count, Staphylococcus aureus and Mould \&yeast count (cfu/g) of the examined lamb carcasses before and after application of acid treatment $(n=25)$

Treatments ( Means \pm standard errors )

\begin{tabular}{|c|c|c|c|c|c|c|c|c|}
\hline \multicolumn{2}{|c|}{ tic acid $1 \%$} & \multicolumn{3}{|c|}{ Lactic acid $2 \%$} & \multicolumn{3}{|c|}{ Acetic acid 1\% } & \\
\hline tal Staph. & Mold \&yeast & Total Salm & Total Staph. & Mold \&yeast & Total Salm & Total Staph. & $\begin{array}{l}\text { Mold } \\
\text { \&yeast }\end{array}$ & \\
\hline $\begin{array}{l}\times 10^{2} \pm \\
3 \times 10^{2} \mathrm{~b}\end{array}$ & $\begin{array}{l}1.78 \times 10^{2} \pm \\
0.210^{2}\end{array}$ & $\begin{array}{c}1.2 \times 10^{2} \pm \\
1 \times 10^{2} \mathrm{a}\end{array}$ & $\begin{array}{l}1.14 \times 10^{2} \pm \\
0.3710^{2} \mathrm{~b}\end{array}$ & $\begin{array}{l}1.21 \times 10^{2} \pm \\
0.2 \times 10^{2} \mathrm{~b}\end{array}$ & $\begin{array}{c}2.8 \times 10^{2} \pm \\
1.8 \times 10^{2} \mathrm{a}\end{array}$ & $\begin{array}{l}1.48 \times 10^{2} \pm \\
0.42 \times 10^{2} \mathrm{~b}\end{array}$ & $\begin{array}{l}1.53 \times 10^{2} \pm \\
0.17 \times 10^{2} \mathrm{a}\end{array}$ & $\begin{array}{l}1.3 \\
1.1\end{array}$ \\
\hline
\end{tabular}




\begin{tabular}{|c|c|c|c|c|c|c|c|c|}
\hline $\begin{array}{l}1 \times 10^{2} \pm \\
6 \times 10^{2} \mathrm{a}\end{array}$ & $\begin{array}{l}1.23 \times 10^{2} \\
\pm 0.14 * 10^{2} \mathrm{a}\end{array}$ & $\begin{array}{l}0.7 \times 10^{2} \pm \\
0.1 \times 10^{2} \mathrm{a}\end{array}$ & $\begin{array}{l}1.26 \times 10^{2} \pm \\
0.57 \times 10^{2} \mathrm{~b}\end{array}$ & $\begin{array}{l}1.26 \times 10^{2} \pm \\
0.57 \times 10^{2} \mathrm{~b}\end{array}$ & $\begin{array}{l}1.4 \times 10^{2} \pm \\
0.4 \times 10^{2} \mathrm{a}\end{array}$ & $\begin{array}{l}1.71 \times 10^{2} \pm \\
0.62 \times 10^{2} \mathrm{a}\end{array}$ & $\begin{array}{l}1.21 \times 10^{2} \pm \\
0.13 \times 10^{2} \mathrm{a}\end{array}$ & 0.6 \\
\hline $\begin{array}{l}6 \times 10^{2} \pm \\
3 \times 10^{2} \mathrm{a}\end{array}$ & $\begin{array}{c}1.03 \times 10^{2} \pm \\
0.1 \times 10^{2} \mathrm{a}\end{array}$ & $\begin{array}{l}0.47 \times 10^{2} \pm \\
0.13 \times 10^{2} \mathrm{a}\end{array}$ & $\begin{array}{c}0.68 \times 10^{2} \pm \\
0.25 \times 10^{2} \mathrm{~b}\end{array}$ & $\begin{array}{c}0.63 \times 10^{2} \pm \\
0.09 \times 10^{2} \mathrm{~b}\end{array}$ & $\begin{array}{c}1 \times 10^{2} \pm 0.2 \\
\times 10^{2} \mathrm{a}\end{array}$ & $\begin{array}{l}1.48 \times 10^{2} \pm \\
0.59 \times 10^{2} \mathrm{a}\end{array}$ & $\begin{array}{l}1.04 \times 10^{2} \pm \\
0.07 \times 10^{2} \mathrm{a}\end{array}$ & 0.4 \\
\hline $\begin{array}{l}8 \times 10^{2} \pm \\
4 \times 10^{2} \mathrm{a}\end{array}$ & $\begin{array}{l}0.77 \times 10^{2} \pm \\
0.08 \times 10^{2} \mathrm{a}\end{array}$ & $\begin{array}{c}0.2 \times 10 \pm \\
0.00 \mathrm{a}\end{array}$ & $\begin{array}{l}1.1 \times 10^{2} \pm \\
0.7 \times 10^{2} \mathrm{a}\end{array}$ & $\begin{array}{l}0.58 \times 10^{2} \pm \\
0.11 \times 10^{2} \mathrm{a}\end{array}$ & $\begin{array}{l}0.6 \times 10^{2} \pm \\
0.2 \times 10 \mathrm{a}\end{array}$ & $\begin{array}{l}1.05 \times 10^{2} \pm \\
0.4 \times 10^{2} \mathrm{a}\end{array}$ & $\begin{array}{l}0.72 \times 10^{2} \pm \\
0.07 \times 10^{2} \mathrm{a}\end{array}$ & \\
\hline $\begin{array}{l}\times 10^{2} \pm \\
2 \times 10^{2} \mathrm{a}\end{array}$ & $\begin{array}{l}1.18 \times 10^{2} \pm \\
0.16 \times 10^{2} \mathrm{a}\end{array}$ & -- & $\begin{array}{l}0.45 \times 10^{2} \pm \\
0.19 \times 10^{2} \mathrm{~b}\end{array}$ & $\begin{array}{l}0.65 \times 10^{2} \pm \\
0.09 \times 10^{2} \mathrm{~b}\end{array}$ & -- & $\begin{array}{l}0.6 \times 10^{2} \pm \\
0.22 \times 10^{2} \mathrm{a}\end{array}$ & $\begin{array}{l}0.79 \times 10^{2} \pm \\
0.09 \times 10^{2} \mathrm{~b}\end{array}$ & \\
\hline $\begin{array}{l}\times 10^{2} \pm \\
\times 10^{2} \text { a }\end{array}$ & $\begin{array}{l}1.48 \times 10^{2} \pm \\
0.0810^{2} \mathrm{a}\end{array}$ & -- & $\begin{array}{c}0.8 \times 10^{2} \pm \\
0.25 \times 10^{2} \mathrm{bc}\end{array}$ & $\begin{array}{c}1.0 \times 10^{2} \pm \\
0.08 \times 10^{2} \mathrm{bc}\end{array}$ & -- & $\begin{array}{l}1 \times 10^{2} \pm \\
0.45 \times 10^{2} \mathrm{a}\end{array}$ & $\begin{array}{l}1.23 \times 10^{2} \pm \\
0.08 \times 10^{2} \mathrm{ab}\end{array}$ & \\
\hline $\begin{array}{l}\times 10^{2} \pm \\
\times 10^{2} \mathrm{a}\end{array}$ & $\begin{array}{l}1.3 \times 10^{2} \pm \\
0.11 \times 10^{2} \mathrm{a}\end{array}$ & -- & $0.4 \times 10^{2} \mathrm{~b}$ & $\begin{array}{l}0.85 \times 10^{2} \pm \\
0.08 \times 10^{2} \mathrm{~b}\end{array}$ & & $\begin{array}{l}0.66 \times 10^{2} \\
\pm 0.4710^{2} \mathrm{a}\end{array}$ & $\begin{array}{l}1.27 \times 10^{2} \pm \\
0.1 \times 10^{2} \mathrm{a}\end{array}$ & \\
\hline
\end{tabular}

Salm.=Salmonella

Staph. $=$

Staphylococcus aureus

Means in the same raw followed by same letters do not differ significantly at $\mathrm{p}=0.05$ within each of Salmonella and Staphylococci count

Mean value of control samples in total Salmonella count $=4.80 \times 10^{2} \pm 3$. $2 \times 10^{2}$

Mean value of control samples in total Staphylococcus aureus count $=$ $2.44 \times 10^{2} \pm .67 \times 10^{2}$

Mean value of control samples in total Mold \&yeast count $=2.93 \times 10^{2}$ $\pm .30 \times 10^{2}$

$\mathrm{Hr}=$ hour

Table (8): Statistical analytical results of total proteolytic and lipolytic counts (cfu/g) of the examined lamb carcasses

\begin{tabular}{|c|c|c|c|c|c|c|c|c|c|}
\hline & \multicolumn{9}{|c|}{ Treatment ( means \pm standard errors ) } \\
\hline & \multicolumn{2}{|r|}{ Control } & \multicolumn{2}{|c|}{ Lactic acid $1 \%$} & \multicolumn{2}{|c|}{ Lactic acid $2 \%$} & \multicolumn{2}{|c|}{ Acetic acid 1\% } & Ac \\
\hline & $\begin{array}{r}\% \\
+\mathrm{ve} \\
\end{array}$ & Mean \pm SEM & $\begin{array}{r}\% \\
+ \text { ve } \\
\end{array}$ & Mean \pm SEM & $\begin{array}{r}\% \\
+ \text { +ve } \\
\end{array}$ & $\begin{array}{c}\text { Mean } \pm \\
\text { SEM }\end{array}$ & $\begin{array}{r}\% \\
+ \text { ve } \\
\end{array}$ & Mean \pm SEM & $\begin{array}{r}\% \\
+\mathrm{ve} \\
\end{array}$ \\
\hline$\%)$ & 92 & $\begin{array}{c}38.19 \pm 7.21 \mathrm{a} \\
-\end{array}$ & 84 & $\begin{array}{c}33.04 \pm 6.29 \mathrm{ab} \\
(13.49) \\
\end{array}$ & 84 & $\begin{array}{c}22.05 \pm 4.19 b \\
(42.26) \\
\end{array}$ & 88 & $\begin{array}{c}29.41 \pm 5.97 \mathrm{ab} \\
(22.99) \\
\end{array}$ & 84 \\
\hline
\end{tabular}


Assiut Vet. Med. J. Vol. 55 No. 122 July 2009

\begin{tabular}{|c|c|c|c|c|c|c|c|c|c}
\hline & & & & & & & & \\
\hline & 88 & $31.95 \pm 1.85 \mathrm{a}$ & & $21.45 \pm 1.73 \mathrm{~b}$ & & $12.88 \pm 1.11 \mathrm{c}$ & & $21.77 \pm 1.73 \mathrm{~b}$ & 88 \\
\hline
\end{tabular}

Number of examined samples per treatment $=25$.

Reduction \% was the deviation of treatment means relative to the control mean.

Means in the same row followed by the same letter do not differ significantly $\mathrm{P}=0.05$. 


\section{دور خميرة البيرة في تحسين المناعة النوعية وغير النوعية في دجاج اللحم في سوريا تحين المناعة فئ}

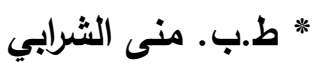

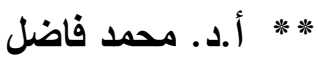

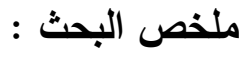

أجريت الدراسة على ( 500) طيراً من إحدى الهجن التجارية لدجاج اللحم ، وقد استخدمت خميرة البيرة Brewer`s yeast أو ما يدعى بالاسم العلمي سكروميزس سبرفيسيا Saccharomyces Cerevisiae ، بشكلٍ مقتولٍ أو (معطل) كمتمٍٍ علفي، حيث أنها تتميز باحتوائها على قيمةٍ غذائيةٍ مرتفعةٍ إضافة إلى احتوائها

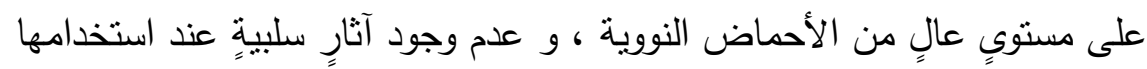

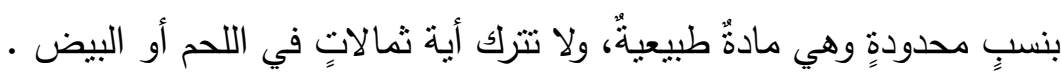

استخدمت الخميرة المقتولة على شكل بودرة ، تم خلطها مع العلف المستخدم حسب خطة الدراسة أثناء عملية تصنيع العلف المستخدم في التجربة ، وحسب الجرعة المحددة في خطة البحث وهي 1000غ خميرة لكل طن علف .

وذللك بغية مقارنة تأثير هذه الخميرة على الاستجابة المناعية النوعية وغير النوعية لمرض الجراب المعدي ، وذلك باستخدام ثلاث أنواع من اللقاحات التجارية المستخدمة في سورية ضد مرض التهاب الجراب المعدي (الجمبورو) ، وهم لقاحين مستوردين (رقم 1- رقم2) ، ولقاح مصنع محلياً (رقم 3) ، و قد أثنتت الدراسة وجود فروق معنوية

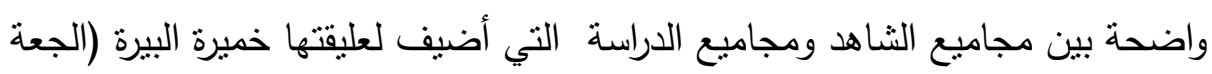
) ، خلال جميع مراحل التربية. سواءً بالنسبة لمعايير الأضداد لمرض الجراب المعدي لئي

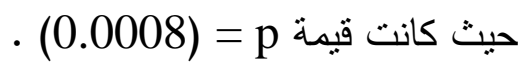


و أثنتت الدراسة وجود فروقٍ معنويةٍ واضحةٍ بين مجاميع الثاهد ومجاميع الدراسة التي

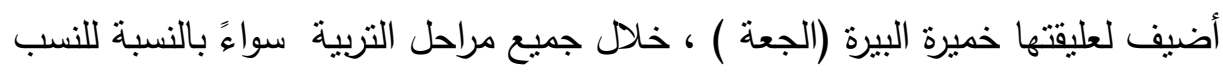

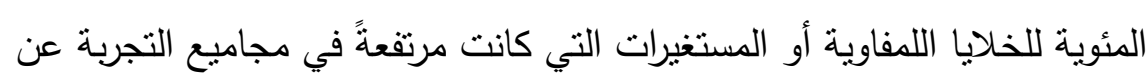

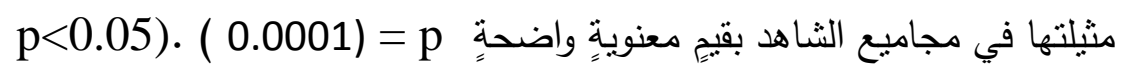

* طالبة دكتوراه - كلية الطب البيطري - جامعة البعث **أستاذ أمراض الدواجن - كلية الطب البيطري - جامعة البعت 


\title{
The Role of Brewer's Yeast in the Improvement of Specific and non- Specific Immunity in Broiler Chickens in Syria
}

\author{
Dr Mona Al. Sharabi ** \\ Dr Mohammad Fadel *
}

\section{Summary :}

The study was conducted on (500) commercial broiler chickens, it has been used Brewer `s yeast, or the so-called scientific name Saccharomyces Cerevisiae in inactive cells as a feed additives.

It contains a high nutritional value in addition to containing a high level of Nucleotides. There are no negative effects when it is used in a limited rates . It is a natural substance and it doesn't leave any residues in meat or eggs .

The inactive Yeast was used in the form of powder which was mixed with the feed used by the study plan during the feed manufacturing process used in the experiment. and according to the specified dose in the research plan, $1000 \mathrm{~g}$ yeast per ton feed.

In order to compare the impact of this yeast on the specific and non- specific immunity of infectious bursal disease ( IBD ) by using three types of commercial vaccines used in Syria against infectious bursal disease. They are two imported vaccines $(1,2)$ and a local vaccine ( 3 ).

The study has confirmed that there were clear significant variances between control and study groups which added to its feed a yeast beer during all stages of breeding either for titers antibodies for IBD ( $\mathrm{P}$ value $=0.0008$ ).

The study has confirmed that there were clear significant variances between control and study groups which added to its feed a yeast beer during all stages of breeding either for the percentage of lymphocytes which were higher in study groups 
than in control groups in clear significant variances ( $\mathrm{P}$ value $=0.0001)$. $(\mathrm{P}<0.05)$.

* Professor of Poultry Diseases, Faculty of vet. Med. , Al-baath university , Hama, Syria .

** phD student in veterinary science, Department of Poultry Diseases, Veterinary Faculty, Al-baath university, Hama, Syria . 
تلعب المناعة الغذائية ( Immuno-nutrition) دوراً واعداً في الوقاية من الأمراض

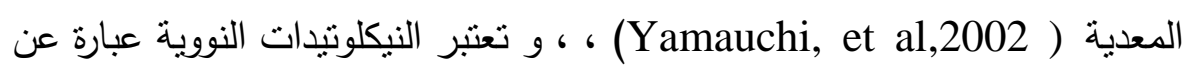
وحدات متسلسلة ضمن الخلايا وهي مهمة حيوياً لأداء وظائف العضويات الحية .

يعتبر مرض الجراب المعدي ( IBD) أو مرض الجمبورو من أهم الأمراض التي تؤدي

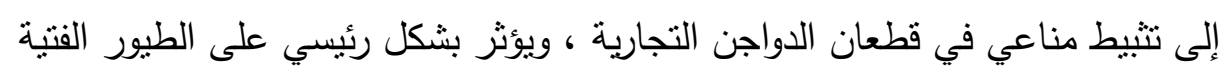

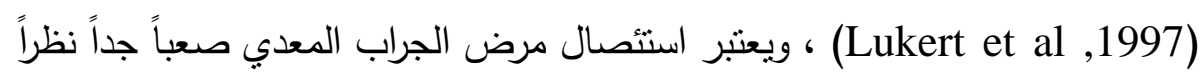

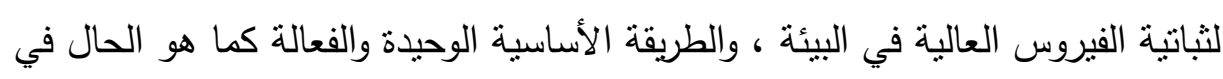

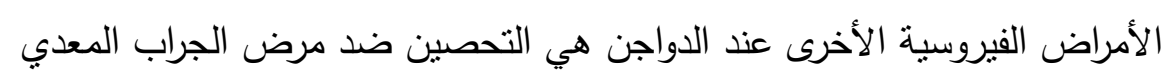

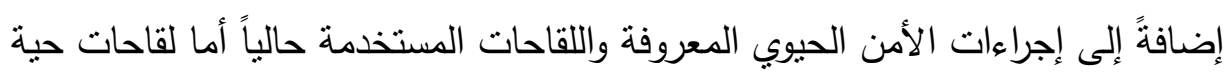

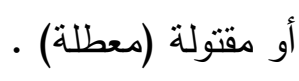

إن الاستراتيجيات الأكثر فاعلية للتحكم بمرض الجراب المعدي تثمل التحصين لطيور

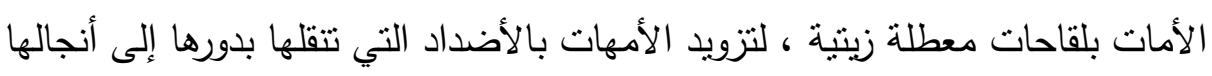

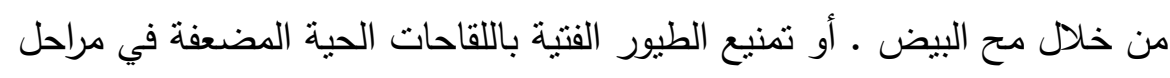

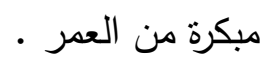

تصاحب بعض أنواع اللقاحات الحية حالة تثبيط مناعي عابر ، والتي يمكن أن نسبب

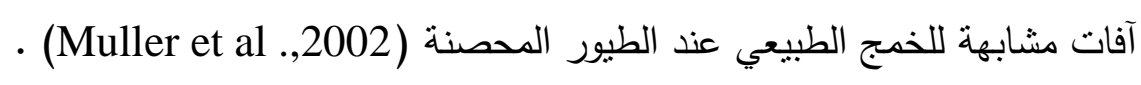

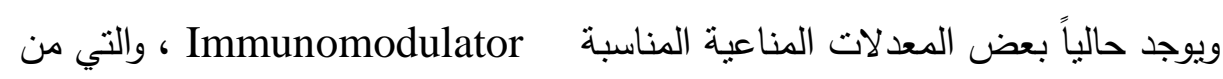

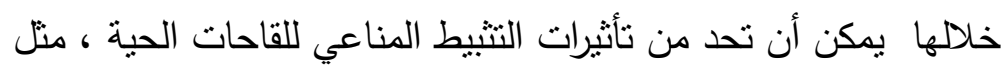

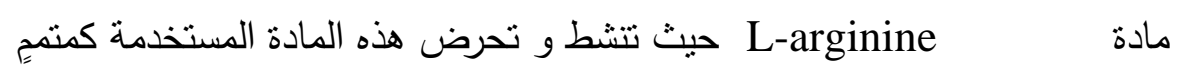

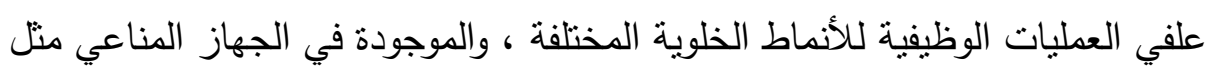

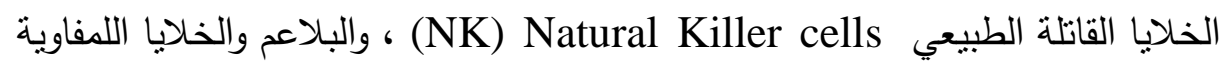

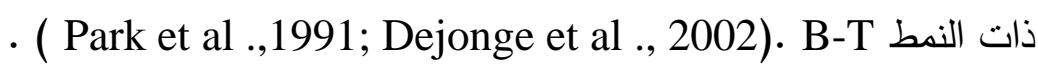


وحيث أن العديد من المُعدلات المناعية ذات النمط الوراثي الحيوي تؤدي إلى تحسين

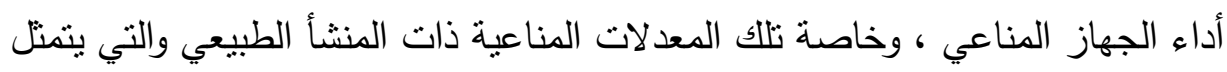
تركيبها بالمستقبلات النيكلوتيدية النووية الطبيعية ، والتي تتضمن البريميدات ومستقبلات البيريميدات والبورينات ، والتي تتواجد في تركيب خميرة الجعة (البيرة) كمكون أساسي باسي لهذه الخميرة بالإضافة أنها تحتوي على مجموعة فيتامينات السيلينيوم ، ونظراً لأن مرض الجراب المعدي يعتبر من أهم الأمراض التي تؤدي إلى لى

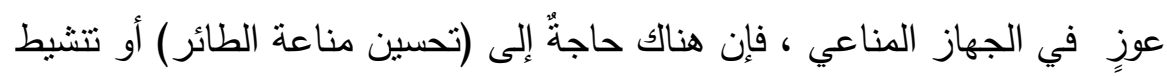

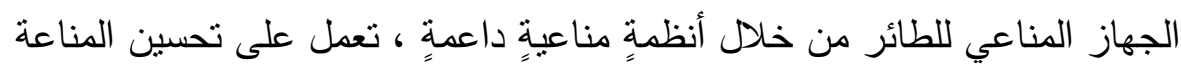

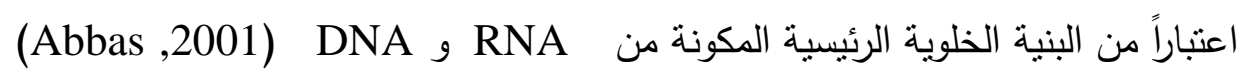

أنثار بعض الباحثنين مثل الباحث ( Whitehead,2003 ) ) ،إن إضافة مركباتٍ تحوي على النيكلوتيدات النووية في المركزات العلفية سوف يساعد في تطوير الخواص البنائية المعوية ، وبالتالي تحسين وظائف القناة المعوية . لمانية ولللك فإن إضافة خميرة البيرة (الجعة) الحاوية على مثل هذه النيكلوتيدات النووية سيؤدي بشكلٍ غير مباشر إلى تحسين معنوي في طول الزغابة المعوية و زيادة في عمق الجزء المخفي للزغابة في منطقة الصائم ، وبالتالي امتصاصٍ أكبر للمواد الغذائية ، ينتج عنه تحسينٌ مناعيٌ أفضل ، وسيساهم ذلك في معدل أفضل للكسب الوزني . استخدمت خميرة البيرة Brewer`s yeast ، أو ما يدعى بالاسم العلمي سكروميزس

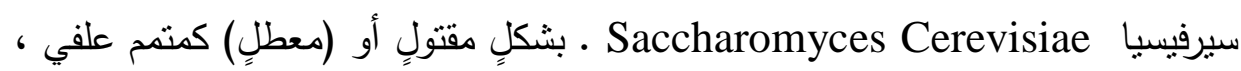

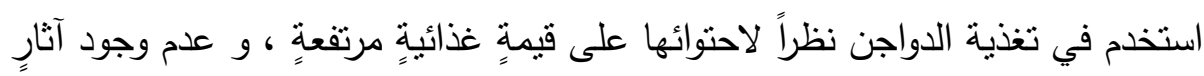
سلبيةٍة عند استخدامها بنسٍ محدودةٍ كمنمٍٍ علفي. - (Carter, H.E and Phillips, 1944 ., Bhattacharjee, 1970) كما وجد الباحث (Stone, 1998) ، أن استخدام خميرة سيركومايسس سرفاي في تغذية دجاج اللحم كمادةٍ طبيعيةٍ توفر الفيتامينات وخاصة مجموعة فيتامين B وكذللك البرونين 
ذو القيمة البيولوجية العالية بعيداً عن السموم وعن المواد المثيرة للحساسية أو المركبات السرطانية عند استخدام مركبات صنعية غير طبيعية .

مواد وطرق العمل Materials and Methods :

مواد العمل Materials : مورد

\section{: 1 الصيصان}

تم تربية ( 500 ) طائر بعمر يوم واحد من أحد الهجن التجارية ، نم الحصول

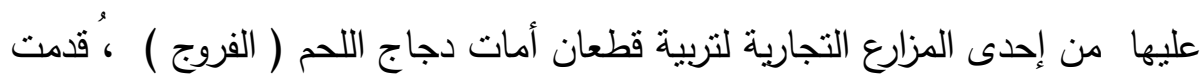
للطيور عليقةً محبحبةً بمراحل مختلفة (مرحلة أولى و مرحلة ثانية ) .

2- 2 - خميرة البيرة (الجعة ) :

استخدمت خميرة البيرة Brewer`s yeast ، أو ما يدعى بالاسم العلمي سكروميزس سيرفيسيا Saccharomyces Cerevisiae ، بشكلٍ مقتولٍ كمتمٍٍ علفي استخدم في ماني

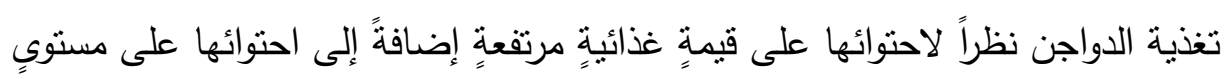
عالٍ من الأحماض النووية ، و عدم وجود آثارٍ سلبيةٍ عند استخدامها بنسٍٍ محدودةٍ كمتمٍٍ علفي.

واستخدمت الخميرة المقتولة على شكل بودرة نم خلطها مع العلف المستخدم حسب خطة الدراسة أثناء عملية تصنيع العلف المستخدم في التجربة بعد أن نم تحضيرها بشكلٍ مقتولٍ من خلال تعريضها لبخار لمدة 4 4) ساعات مع الحفاظ على درجة الحرارة

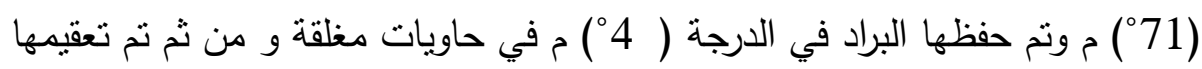

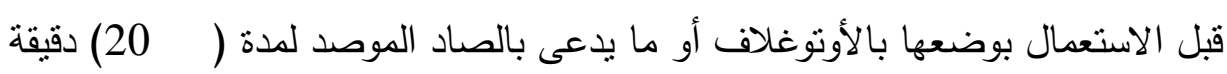
تحت ضغط (15) بار (BAR) و بدرجة حرارة (115) درجة مئوية

وحسب الجرعة المحدة في خطة البحث وهي 1000غ /طن من العلف .

Methods : طرق العمل 


\section{1 - The Study Groups مجاميع الدراسة}

استخدم ( 500 ) صوص بعمر يوم واحد ، من أحد الهجن التجارية ، "قسمت

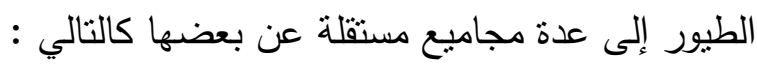

مجاميع الشاهد : شملت (200) طير قدمت لها عليقةٌ محبحبةٌ خاليةٌ من خميرة البيرة (الجعة ) قسم الثاهد إلى ثلاث مجاميع وفقا لنوع لقاح الجمبورو الذي سيتم تحصين الطيور به :

المجموعة الأولى : مجموعة الثاهد رقم (1) : وهي (66) طيراً قدمت لها عليقةٌ خاليةٌ تماماً من الخميرة حصنت باللقاح رقم (1). المجموعة الثانية : مجموعة الثاهد رقم (2) : وهي (66) طيراً قدمت لها عليقهٌ خاليةٌ تماماً من الخميرة حصنت باللقاح رقم (2). المجموعة الثالثة : مجموعة الثاهد رقم (3) : وهي (68) طيراً قدمت لها عليقةٌ خاليةٌ تماماً من الخمبرة حصنت باللقاح رقم (3). مجاميع التجرية : وهي عبارة عن ( 300) طيراً قدمت لها عليقةٌ محبحبةٌ تحوي على

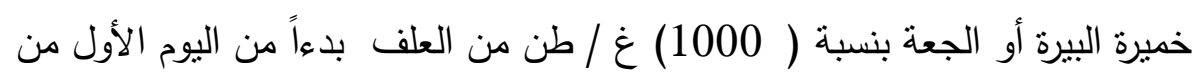

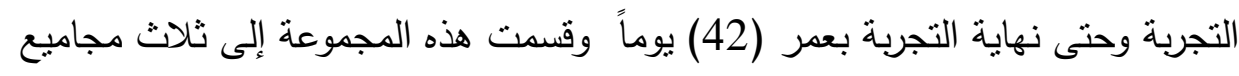

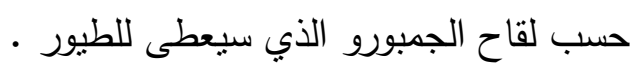

المجموعة الأولى : مجموعة التجربة رقم (1) : وتحوي على (100) طير تم تحصينها

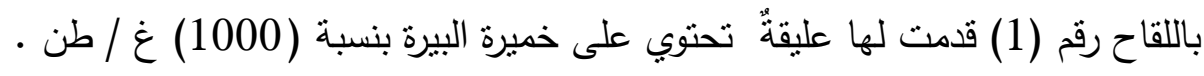
المجموعة الثانية : مجموعة تجربة رقم ( 2) : وهي تحوي على ( 100) طير نم

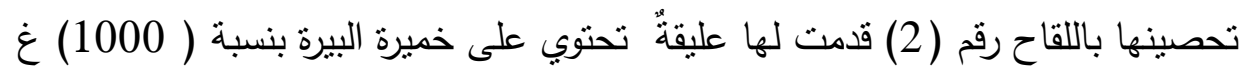
· / 
المجموعة الثالثة : مجموعة تجربة (3): وهي تحوي على (100) طير تم تحصينها

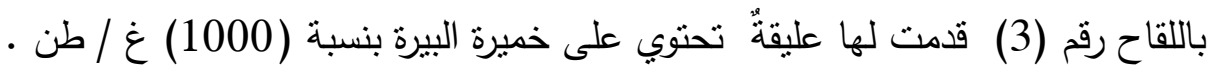
وقد تم تغذية الطيور بعلف محبحب ، وتم مراعاة الاحتياجات الغذائية حسب متطلبات الطيور في جميع مراحل التربية .

\section{عانات الدم Blood Samples}

هُوقد تم جمع عينات الدم دورياً و بفترة زمنية فاصلة ( 5-7) أيام ، تم إضافة مانع

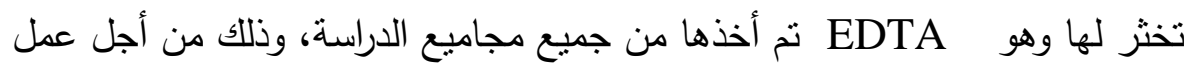
شرائح دموية للعد التقريقي لكريات الدم البيضاء ، وذلك لقياس المناعة غير النوعية Simple Random ) عند طيور التجربة ـ أخذت عينات الدم بطريقةٍ عشوائيةٍ بسيطة (Sampling حسب الباحث كاميرون ( Cameron, 1999 ) كما أخذت عينات دم أخرى لم يضاف لها مانع تخثر، تم تثقيلها وفصل المصل منها ومن ثم تم حفظها بمجمدات في درجة (- 30) درجة مئوية ليتم معايرة الأضداد النوعية لمرض الجراب المعدي (مرض الجمبورو) في هذه الأمصال التي تم جمعها من كل مجاميع

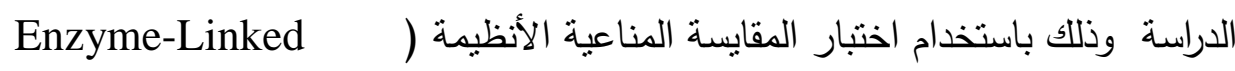
- (ELISA) (Immunosorbent Assay

\section{- Serological Tests الاختبارات المصلية -}

أجريت الدراسة المصلية باستخدام اختبار المناعة المرتبطة بالأنظيم

Enzyme-Linked Immunosorbent Assay ( ELISA )

لمعرفة مستوى الأضداد النوعية لمرض الجراب المعدي في مصل الدم ، و 'يعد هذا الاختبار هو المفضل في عمليات التقصي المصلي لأعداد كبيرة من العينات بالنسبة لمرض الجراب المعدي ( Lee\&Lin,1992) (IBD) ) و استخدمت طريقة الباحثون 
. لإجراء الاختبار و خطوات العمل حسب توصيات الثركة (Pick et al., 1981) المنتجة للمجموعة التشخيصية .

$$
\text { الثرائح الاموية }
$$

كما نم صنع شرائح دموية تحوي على أفلامٍ دمويةٍ رقيقةٍٍة من عينات الدم التي أضيف

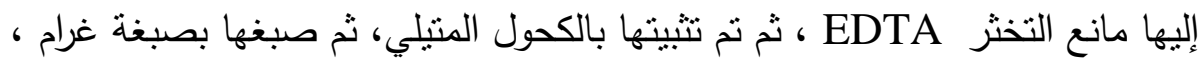
ومن ثم تمت القراءة المجهرية لها ، لدراسة وحساب النسبة المئوية لأنواع الكريات

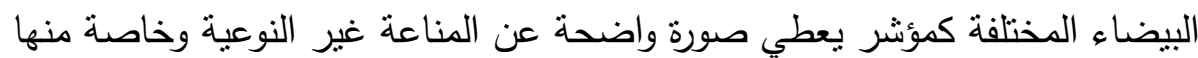
الخلايا اللمفاوية . الناه

\section{- طريقة التحليل الإحصائي : Statistic Analysis Method}

درست الفرو قات في معايير الأضداد بين مجا ميع الدراسة المختلفة باستخدام طريقة التحليل الوحيدة للفرق One Way Analysis of Variance كما تم دراسة الفروق في النسب المئوية للخلايا اللدفاوية وكذلك خلايا المستغيرات وبقية

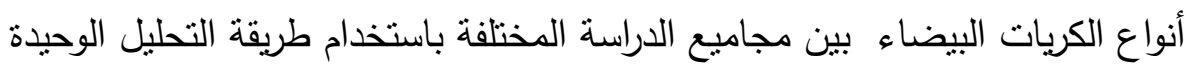
للفرق One Way Analysis of Variance

استخذم برنامج التحليل على الحاسوب (Statistix , 1998 ) ، لإجراء جميع التحاليل الإحصائية في هذه الدراسة .

النتائج Results

1- تأثير خميرة البيرة (الجعة ) على المناعة النوعية :

\section{Impact of Brewer`s yeast on Specific Immunity}

One-Way- مقارنة معايير الأضداد باستخدام طريقة التحليل الوحيدة للفرق :Analysis of Variance 
تم استخدام طريقة تحليل الفرق الوحيد لمقارنة معايير الأضداد بين مجموعات الثاهد ومجاميع الدراسة التي أضيف لها خميرة البيرة أو الجعة ، حيث تبين أن هناك فروقاً

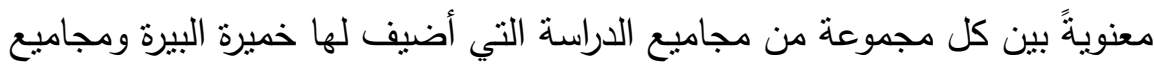

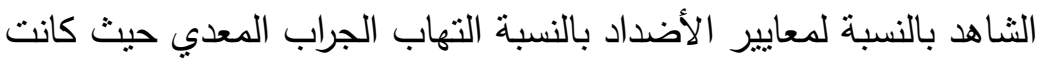
قيمة

يوضح الجدول رقم (1) مقارنة معايير الأضداد لمرض التهاب الجراب المعدي باستخدام طريقة تحليل الفرق الوحيد بين مجاميع الدراسة المختلفة خلال فترة التربية التجريبية

\begin{tabular}{|c|c|c|c|c|c|c|}
\hline تجربة 3 & شاهد 3 & تجربة2 & شاهد 2 & تجربة 1 & شاهد 1 & الطيور \\
\hline 3322.7 & 3322.7 & 3322.7 & 3322.7 & 3322.7 & 3322.7 & 5 يوم \\
\hline 3928 & 3446.4 & 3928 & 3446.4 & 3928 & 3446.4 & 13 يوم \\
\hline 4559.8 & 3585 & 4182.8 & 3626.6 & 4086.2 & 3471.4 & 22يوم \\
\hline 5540.2 & 5188.6 & 4798.3 & 3654.3 & 5445.7 & 3791.7 & 29 يوم \\
\hline 8504.2 & 5765.7 & 6561.6 & 6458.9 & 7950.4 & 6491 & 36 يوم \\
\hline 15662 & 12865 & 15152 & 12023 & 15528 & 12584 & 41 يوم \\
\hline
\end{tabular}

$(\mathrm{P}=0.0008<0.05)$

المخطط البياني (1) مقارنة معايير الأضداد لمرض التهاب الجراب المعدي باستخدام طريقة تحليل الفرق الوحيد بين مجاميع الدراسة المختلفة خلال فترة التربية التجريبية 
2- تأثثر خميرة البيرة (الجعة ) على المناعة غير النوعية :

\section{Impact of Brewer`s yeast on non- Specific Immunity}

مقارنة النسب المئوية للخلايا اللمفاوية والمستغيرات باستخام طريقة التحليل الوحيدة للفرق One-Way-Analysis of Variance:

تم استخدام طريقة التحليل الوحيدة للفرق بين مجاميع الثاهد التي لم يضاف لغذائها

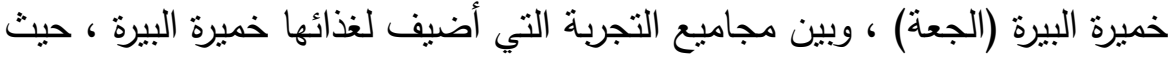

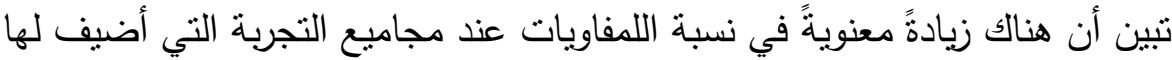
خميرة البيرة مع غذائها عنها في مجاميع الثاهد التي لم يضاف لها مع غذائها خميرة البيرة (الجعة) ، حيث P<0.05) وانخفضت بالدقابل نسبة خلايا المستغيرات

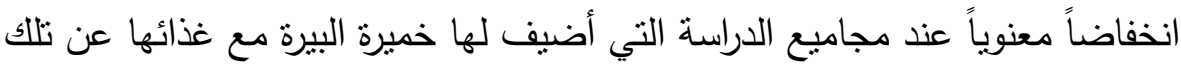
في الثاهد التي لم يضاف لها مع غذائها الخميرة حيث (P>0.05).

الجدول رقم (2) مقارنة النسب المئوية للخلايا اللمفاوية بين مجاميع الدراسة المختلفة خلال فترة التربية التجريبية

\begin{tabular}{|c|c|c|c|c|c|c|}
\hline التجرية 3 & الثشاهد 3 & التجربة 2 & الثاهد 2 & التجرية 1 & الثشاهد 1 & \\
\hline 35.2 & 33.6 & 34.1 & 33.7 & 31.9 & 30.2 & عمرالطيور 7 \\
\hline 37.5 & 35.5 & 36.4 & 34.7 & 35.3 & 34.4 & 14 عمرالطيور \\
\hline 45.3 & 43.3 & 44.2 & 43.1 & 43.8 & 42.7 & 21 عمرالطيور \\
\hline 49 & 46 & 48.2 & 47.1 & 47.8 & 46.5 & 28 عمرالطيور \\
\hline
\end{tabular}


Assiut Vet. Med. J. Vol. 55 No. 122 July 2009

\begin{tabular}{|l|c|c|c|c|c|c|}
60 & 55 & 58 & 55.2 & 57.2 & 56.4 & $\begin{array}{c}\text { عمرالطيور } \\
35\end{array}$ \\
\hline 63 & 50 & 62.2 & 59.9 & 61.2 & 59 & $\begin{array}{c}\text { يورالطيور } \\
\text { يور }\end{array}$ \\
\hline
\end{tabular}

المخطط البياني رقم (2) مقارنة النسب المئوية للخلايا اللمفاوية بين مجاميع الدراسة المختلفة خلال فترة التربية التجريبية

$$
\text { حيث كانت (P<0.05) }
$$


Assiut Vet. Med. J. Vol. 55 No. 122 July 2009

الجدول رقم (3) مقارنة النسب المئوية لخلايا المستغيرات بين مجاميع الدراسة المختلفة خلال فترة التربية التجريبية

\begin{tabular}{|c|c|c|c|c|c|c|}
\hline التجرية 3 & الثـاهد 3 & التجرية 2 & الثاهد 2 & التجرية 1 & الثاهد 1 & \\
\hline 50.6 & 52.8 & 51.9 & 53.3 & 51.1 & 52.4 & عمرالطيور 7 \\
\hline 47.7 & 48.7 & 47.6 & 47.9 & 49.9 & 48.6 & عمرالطيور 14 يوم \\
\hline 37.7 & 38.7 & 37.5 & 39.1 & 37.9 & 38.2 & عمرالطيور 21 يوم \\
\hline 32 & 34 & 33.8 & 34.2 & 33.5 & 34.5 & عمرالطيور 28 يوم \\
\hline 23 & 25 & 24 & 24.5 & 23.8 & 24.3 & عمرالطيور 35 يوم \\
\hline 22 & 23 & 22.6 & 22.8 & 21.5 & 22.4 & عمرالطيور 42 يوم \\
\hline
\end{tabular}


المخطط البياني رقم (3) مقارنة النسب المئوية لخلايا المستغيرات بين مجاميع الاراسة المختلفة خلال فترة التربية التجريبية مفرنه

$$
\text { حيث كانت }
$$

Discussion: المناقشة

قدمت هذه الدراسة ، والتي استخدمت أحد المحسنات المناعية ممثلة بخميرة البيرة أو الجعة Brewer`s yeast ، أو ما يدعى بالاسم العلمي سكروميزس سيرفيسيا

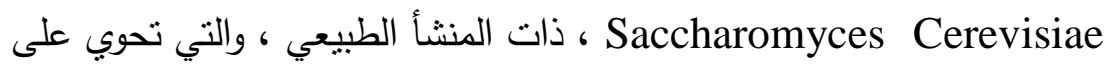
النيوكلوتيدات النووية بالإضافة إلى فيتامين B وعنصر السيلينيوم وغيرها من العناصر

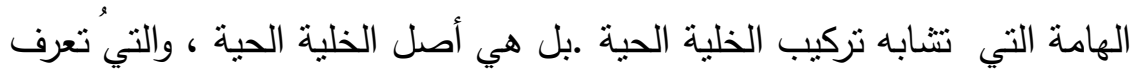
بالنيوكلوتيدات النووية ،وبهذا تقدم للخلية الطاقة اللازمة لعملية الانقسام الخلوي مباشرة بالإضافة إلى المواد الهامة في بناء الخلية ، وهذا يؤدي إلى قصر في فترة إنجاز عملية

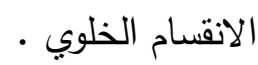

أثنتت الدراسة وجود فروق معنوية واضحة بين متوسط معايير الأضداد لمرض الجراب المعدي (الجمبورو ) بين مجموعات الثاهد ومجاميع الدراسة ، حيث كانت قيمة

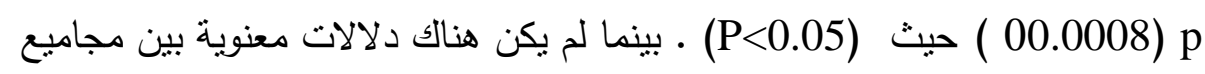

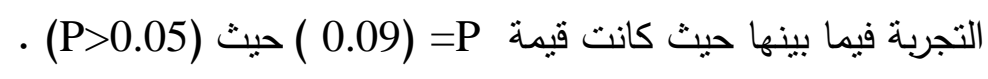

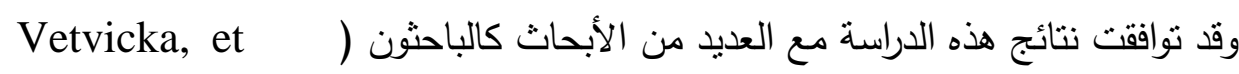

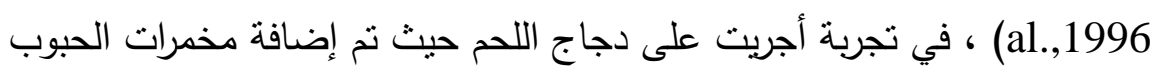
beta- Brewer`s grains

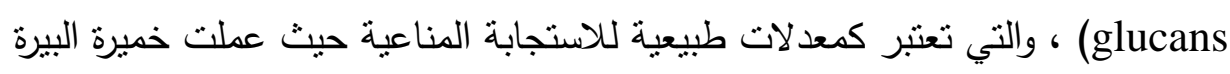
على تحفيز الأجسام المضادة المناعية بعد التحصين ضد فيروس النيوكاسل ، وعند قياس معيار الأجسام المضادة المناعية ضد مرض النيوكاسل في طيور دجاج اللحم المحصن الذي غذي على علف يحوي الخميرة كانت أعلى بفروق معنوية واضحة مقارنة مع مجموعة الثاهد التي لم يضاف لعلفها خميرة البيرة أو الجعة . 


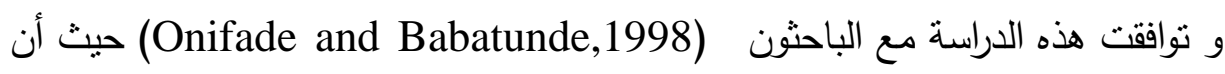
إضافة خميرة البيرة يؤدي لزيادة الوزن وزيادة مقاومة الطائر لمقاومة الأمراض المعدية ، وذللك عند معايرة الأجسام المضادة المناعية لمرض النيوكاسل .

وتوافقت أيضا مع الباحث ( Navarro,et al.,1996) حيث أكد أن إضافة النيوكلوتيدات النووية المناعية لها تأثير محفز للجهاز المناعي ، ويؤدي لإنتاج أجسام

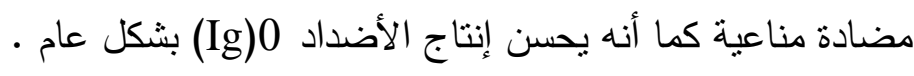

أثتبت الدراسة وجود زيادةً معنويةً واضحةً في نسبة الخلايا اللمفاوية لهجاميع التجربة

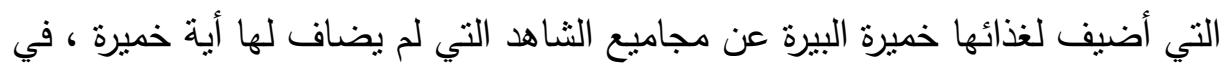

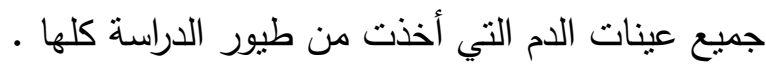

$$
\text { فكانت قيمة (p=0.0001) حيث نجد (P<0.05) }
$$

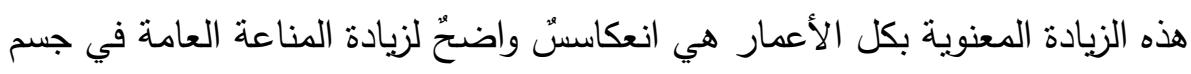

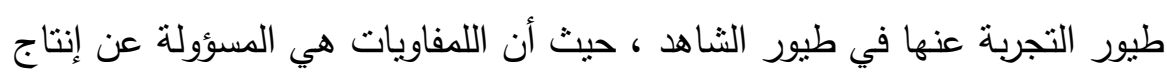
الأضداد ، وهذا مؤشرُ واضحّ على تحفيز وتتشيط الجهاز المناعي.

أما بالنسبة لخلايا المستغيرات فقد انخفضت في مجاميع التجربة التي أضيف لها في

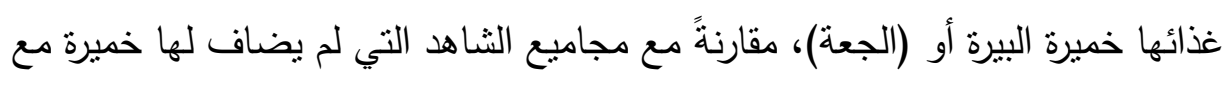

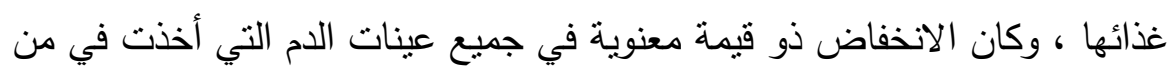

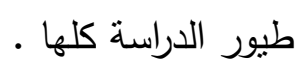

$$
\text { وكانت قيمة (p=0.0123) حيث نجد (P<0.05) }
$$

وهذا الانخفاض يدل على تراجع العمليات الالتهابية في جسم الطيور، وذلك للفعالية

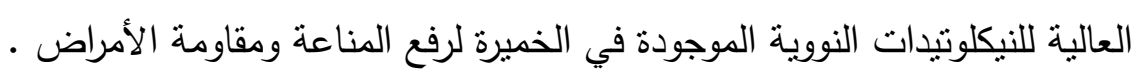
وقد نوافقت نتائج هذه الدراسة مع العديد من الأبحاث Aggett et al., 2002; and Adjei, ) كالباحثن 
1993)، إن إضافة مركبات تحتوي على النيوكليوتيدات النووية كمتممات علفية يمكن

أن يحرض و يحسن المناعة الخلوية الوسيطة مرحي Lymphocyte proliferation وإنتاج اللمفاويات (Van Buren et al., 1983) (Yamauchi et al., 1996) ، و تحسين مقاومة العائل عموماً و مقاومة الأخماج (Van )

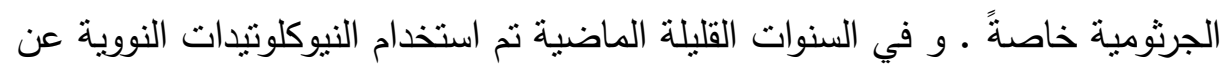
طريق إضافتها مع غذاء الطيور كمتمم علفي لتحسين الوظائف المناعية ، و تحسين

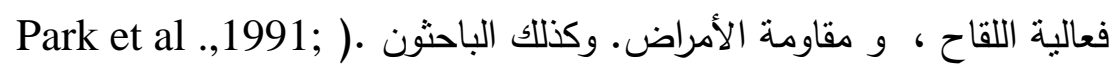

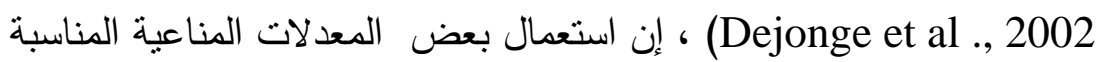

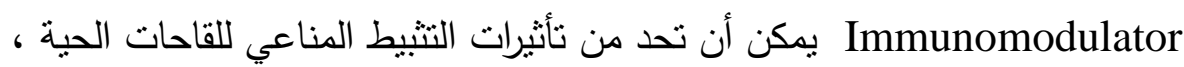
كما ينشط و يحرض الأنماط الخلوية المختلفة الموجودة في الجهاز المناعي مثل الخلايا القاتلة الطبيعي (NK) Natural Killer cells) ، والبلاعم والخلايا اللمفاوية ذات

النمط B-T

\section{Conclusion : الاستنتاج}

مما تبين نجد أن استخدام خميرة البيرة أو الجعة يعتبر محفز للمناعة للوقاية من

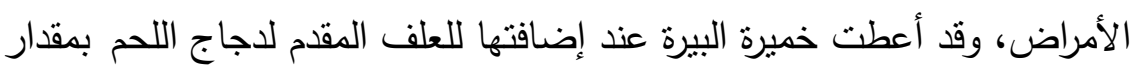

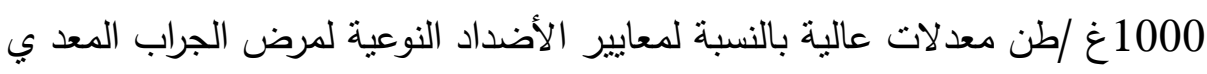

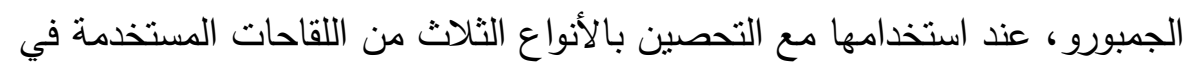

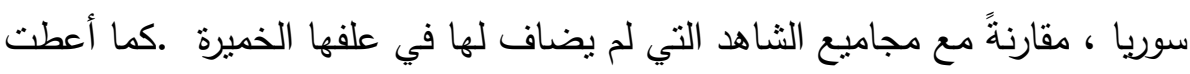
نسبةً عاليةً من الخلايا اللمفاوية ، لمجاميع التجربة التي أضيف لغذائها خميرة البيرة، عن تلك في مجاميع الثاهد التي لم يضاف لها أية خميرة ، هذه الزيادة المعنوية بكل

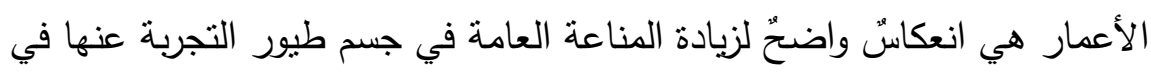

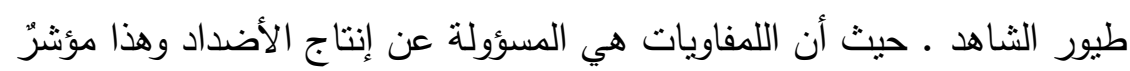

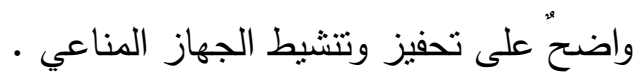


References:

1) Abbas, A. K., and A. H. Lichtman. Basic Immunology: Functions and Disorders of the Immune System . Philadelphia: W. B. Saunders Co., 2001. pp 28-61

2) AGGETT, R., LEACH J. L., RUEDA, R., MACLEAN, W. C. (2002)-Innovation in Infant Formula Development: A Reassessment of Rib nucleotides. Nutrition Journal, Vol. 19, No. 375-84.

3) ADJEI, A. A., TAKAMINE, F. YOKOYAMA, H. SHIOKAWA, K., MATSUMOTO, Y., ASTO, L. (1993)The effects of oral RNA and Intraperitoneal Nucleoside- Nucleotide Administration on MethillinResistant Staphylococcus Aurous Infection in Mice. Journal of Parenter Enteral Nutrition. Vol. 17, No. 148-52. 
4) Bhattacharjee, J.K.1970- Microorganisms as Potential Sources of Food, Advan. Appl. Microbiol., 13, 139-161

5) CARTER,H. E., AND G. E. PHILlIPS 1944 Nutritive value of yeast protein.Federation Proe., 3: 123-128.

6) Cameron A (1999) Survey Toolbox A Practical Manual and Software Package for Active Surveillance of Livestock Diseases in Developing Countries. Australian Centre for International Agricultural Research Monograph No. 54. pp 37 - 47

7) De Jonge WJ,Kwikkers WL.teVelde AA,van Deventer SJ,Notlte MA,Mebius RE,et al .2002-Arginine deficiency affects early $B$ cell maturation and lymphoid orgqn development in transgenic mice. $\mathrm{J}$ Clin Invest, 110.(10):1539-48.

8) Lukert, P.D ., Saif , Y .M . 1997- infectious bursal disease in:B.W.Calnek , H .J. Barnes ,C.W.Beard, L.R. McDouglad , Y.M. Saif (Eds) ., diseases of Poultry, 10 th ed, lowa state University press ,Ames , IA , PP.721-738 .

9) Lee,L.H.andLin,Y.P. 1992-Amonoclonal antibody capture enzyme - linked Immunosorbent assay for Detecting antibodies to infectious bursal disease virus.Journal of virological methods,36:13-23.

10)Muller, H., Islam , R., and Raue,R. ,2002-. Research on Infectious Bursal Diseas the past,the present and the future. Veterinary Microbiology Journal,97:153-165

11)Navarro, J., A. Ruiz-Bravo, M. Jimenez-Varela, and. A. Gil. 1996. Modulation of antibody-forming cell and mitogen-drive lymphoproliferative responses by die- tarynucleotides in mice. Immunology Letters 53:141-145. 
12)Onifade, A.A. and G.M. Babatunde, 1998Comparisonthe utilization of palm kernel meal, brewers' driedgrains and maize offal by broiler chicks. Br. Poult.Sci., 39: 245-250.

13) Park KG,Hayes PD,Garlick PJ,Sewell H,Eremin O.1991-Stimulation of lymphocyte natural cytotoxicity by L-arginine.Lancet. 16.337(8742):645-

14) PICK, E., MIZEL, D. 1981- Rapid Microassays for the Measurement of Superoxide and Hydrogen Peroxidase Production by Macrophages in Culture Using an Automatic Immunoassay Reader. Journal of Immunol Methods, Vol: 46:211-26.

15) Stone, C. 1998- Yeast products in the feed industry. Ed. By Mills, d. Inc. Cedar Rapids, Iowa., p. 10-11.

16) STATISTIX, 1998- Analytical Softewar, Guideline manual, Version, 2.0. USA.

17) Van Buren, C. T., KLKARNI, A. D., SCHANDLE, V. B., RUDOLPH, F. B. (1983)-The Influence of Dietary Nucleotides on Cell-Mediated Immunity. Transplantation Journal, Vol. 36, No. 350-2.

18) Vetvicka, V., B.P. Thornton and G.D. Ross, 1996Soluble beta-glucan polysaccharide binding to the lectin of neutrophil or natural killer cell complement receptor type $3(\mathrm{CD} 11 \mathrm{~b} / \mathrm{CD18})$ generates a primed state of the receptor capable of mediating cytotoxicity of iC3b-opsonized target cells. J Clin Invest. 1996;98(1):50-61. doi:10.1172/JCI118777

19)WHITEHEAD, J. A 2003- Effect of Ascogen on intestinal Morphology and the Performance of the Broiler Chicken. University of Nottingham, UK. 
20) YAMAUCHI, K., ADJEI, A. A., AMEHO, C. K., CHAN, Y. C., KULKARNI, A. D. SATA. (1996)- $\underline{\mathbf{A}}$ nucleoside-Nucleotide Mixture and Its Components Increase Lymph proliferative and Delayed Hypersensitivity Responses in Mice. Journal of Natural, Vol. 126, No. 1571-7. 